\title{
40. PETROLOGY AND CARBON AND OXYGEN STABLE ISOTOPIC COMPOSITION OF MACROFOSSILS AND SEDIMENTS FROM THE BLAKE-BAHAMA FORMATION, DEEP SEA DRILLING PROJECT SITE 603, WESTERN NORTH ATLANTIC LOWER CONTINENTAL RISE ${ }^{1}$
}

\author{
Janet A. Haggerty, Department of Geosciences, University of Tulsa ${ }^{2}$
}

\begin{abstract}
Strata that record the evolutionary history of the North American continental margin in a region that serves as the basin margin interface between allochthonous sedimentation from the continent and pelagic sedimentation from the oceanic realm were recovered at Deep Sea Drilling Project Site 603, on the lower continental rise. The lowermost unit recovered at this site is composed of upper Berriasian-Aptian interbedded laminated limestone and bioturbated limestone with sandstone to claystone turbidites. This unit can be correlated with the Blake-Bahama Formation in the western North Atlantic. Studies of the laminated and bioturbated limestones were used to determine the depositional environment. Geochemical and petrographic studies suggest that the laminated limestones were deposited from the suspended particulate loads of the nepheloid layer associated with weak bottom-current activity as well as moderate to poorly oxygenated bottom-water conditions.

Fragments of macrofossils are also found in the Blake-Bahama Formation drilled at Site 603. Twelve specimens and their host sediment were analyzed for their carbon and oxygen isotopic composition. The macrofossil samples chosen for analysis consist of nine samples of Inoceramus, two ammonite aptychi, and one belemnite sample. Depletion in ${ }^{18} \mathrm{O}$ is observed in recrystallized specimens. The ammonite aptychi have been diagenetically altered and/or exhibit evidence of isotopic fractionation by the organism. Oxygen isotope paleotemperatures obtained from five well-preserved specimens-four of Inoceramus and one of a belemnite-suggest that bottom-water temperatures in the North Atlantic Basin during the Early Cretaceous were very warm, at least $11^{\circ} \mathrm{C}$.
\end{abstract}

\section{INTRODUCTION}

Hole 603B, drilled on DSDP Leg 93, penetrated $1585 \mathrm{~m}$ of section. This is the first deeply buried sediment recovered from beneath the lower continental rise of the western North Atlantic Basin. The site is located in $4633 \mathrm{~m}$ water depth, approximately $435 \mathrm{~km}$ from Cape Hatteras, North Carolina (Fig. 1). Site 603 is located adjacent to the lower continental rise terrace in the first valley of the lower continental rise hills. The position of the site, and improvements in drilling technology since the early legs of the Deep Sea Drilling Project, make drilling results at this site uniquely different from the drilling results at previous DSDP sites in the western North Atlantic. Strata recovered at Site 603 record the evolutionary history of the continental margin in a region functioning as the basin margin interface between allochthonous sedimentation from the continent and pelagic sedimentation from the oceanic realm.

The sedimentary section recovered at Site 603 is divided into five lithologic units (I through V; Lithology section in Site 603 chapter, this volume). These five units can be correlated with the oceanic formations proposed for the western North American Basin by Jansa et al. (1979). The deepest unit (Unit V) is composed of $261 \mathrm{~m}$ of upper Berriasian-Aptian interbedded laminated limestone and bioturbated limestone with sandstone to clay-

\footnotetext{
${ }^{1}$ van Hinte, J. E., Wise, S. W., Jr., et al., Init. Repts. DSDP, 93: Washington (U.S. Govt, Printing Office).

2 Address: Dept. of Geosciences, University of Tulsa, 600 South College Avenue, Tulsa, OK 74104 .
}

stone turbidites. This unit is the local equivalent of the upper portion of the Blake-Bahama Formation as defined by Jansa et al. (1979) from the type locality at DSDP Site 391 (Benson, Sheridan, et al., 1978).

The author uses the term "laminated limestone" rather than "laminated marl" as listed in the Site 603 chapter (this volume), because the carbonate content in these rocks is usually greater than $60 \%$. The term "marl" is used for rocks that contain 30 to $60 \%$ carbonate, with the remaining components being mostly clays (see Explanatory Notes, this volume).

The sedimentologists on board Leg 93 divided Unit V into two subunits on the basis of the presence or absence of turbidites. Subunit VB, upper Valanginian to upper Berriasian, lacks turbidites. Subunit VA, Aptian to upper Valanginian, contains numerous turbidites. The presence of terrigenous clastic turbidites in Subunit VA makes the Blake-Bahama Formation at Site 603 different from other DSDP sites. The Blake-Bahama Formation is characterized by cycles of laminated marlstone or limestone and bioturbated limestone (Fig. 2). Another interesting feature in the Blake-Bahama limestones of Unit V at Site 603, is the inclusion of fragments of macrofossils. Macrofossils are not abundant in these limestones, but their occurrence is usually associated with the laminated limestone; they are rarely found in the bioturbated limestone.

The purpose of this chapter is to investigate the depositional environment of the limestones of the Blake-Bahama Formation, and the carbon and oxygen stable isotopic composition of the limestones and their macrofossils, with the goal of elucidating the early history of this 


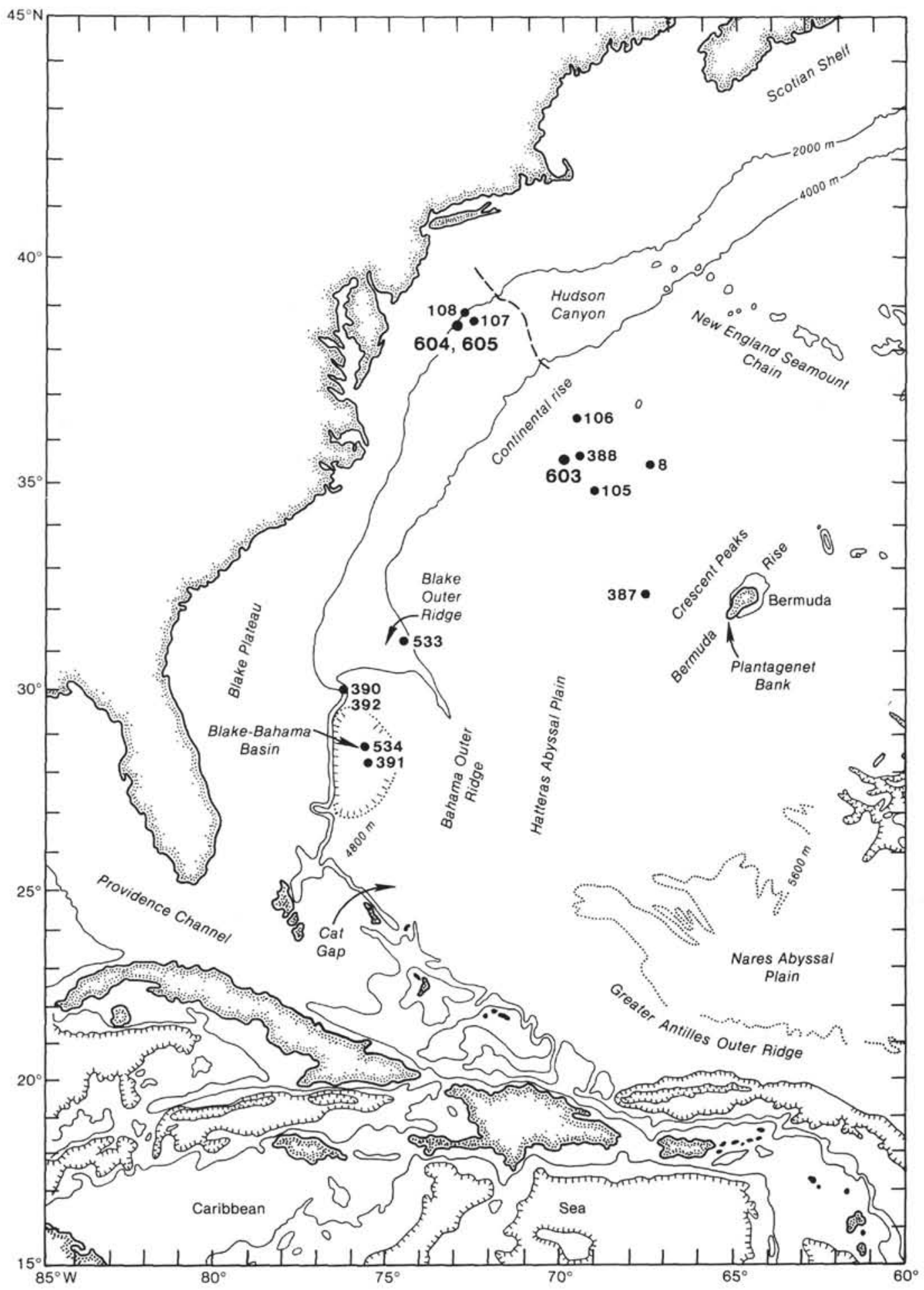

Figure 1. Location map with physiographic features of the North American Basin and location of DSDP sites (from Legs $2,11,43,44,76$, and 93). Site 603 is located in $4633 \mathrm{~m}$ water depth on the lower continental rise. Bathymetry after Uchupi (1971).

restricted, narrow, and youthful North Atlantic Ocean basin. Determination of oxygen isotope paleotemperatures can provide valuable data for understanding the paleoenvironment of the Early Cretaceous North Atlantic.

A vast number of paleotemperature estimates have been made on outcrops of Cretaceous strata that were deposited in the Cretaceous epicontinental seas. Several studies have analyzed the isotopic composition of Inoceramus and belemnites from these shallow sea deposits (Lowenstam and Epstein, 1954; Stevens and Clayton, 1971). Skeletons from these organisms were chosen for analysis because they are not as susceptible to diagenetic alteration as many other skeletal remains. However, their 


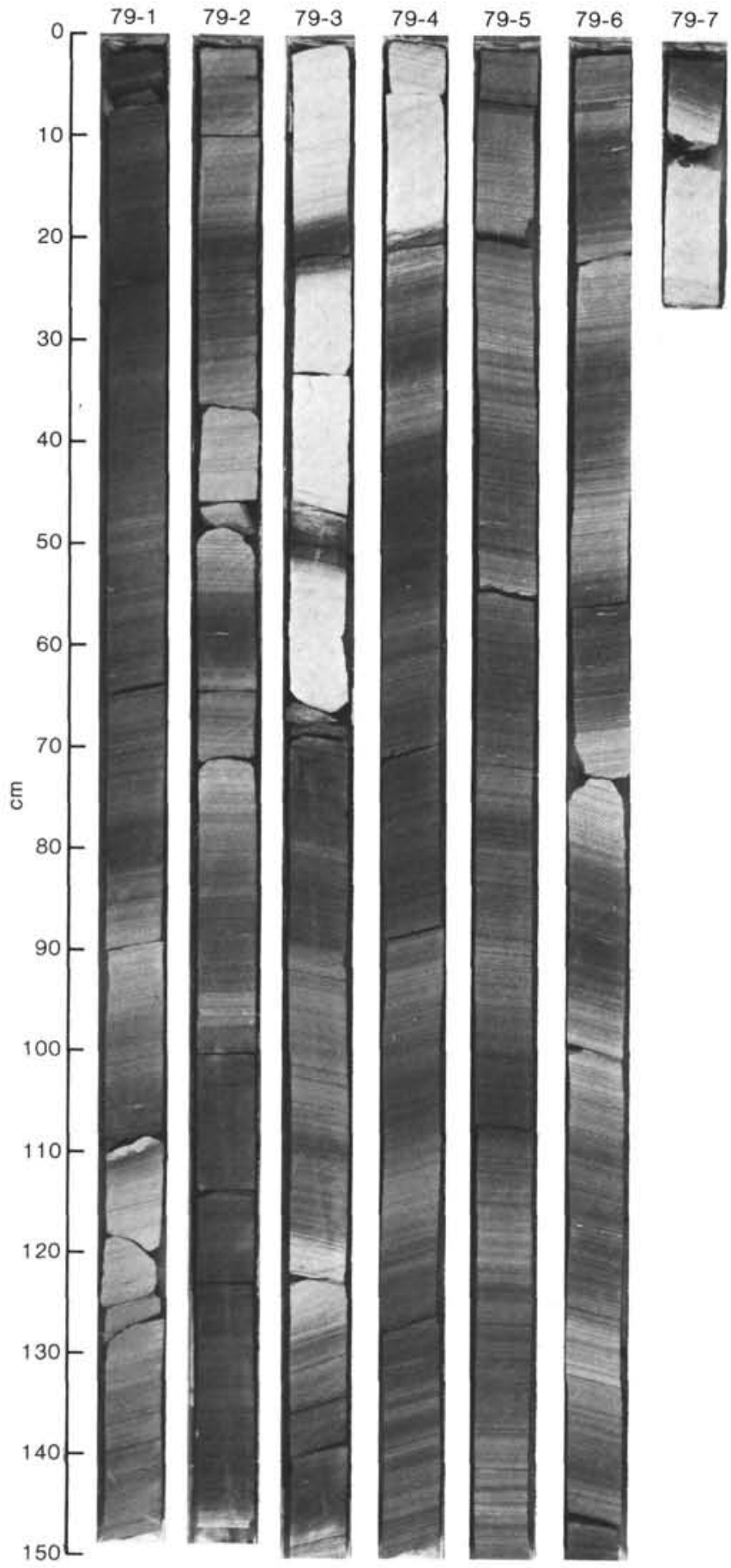

Figure 2. Typical core from the Blake-Bahama Formation. Note the characteristic alternations of laminated limestone with bioturbated limestone. The core is from Subunit VB, therefore clastic terrigenous turbidites are not present. This core (603B-79) contains fragments of macrofossils in the laminated limestone.

coarse crystalline nature and calcite mineralogic composition is not always sufficiently resistant to diagenetic alteration from subaerial exposure and meteoric diagenesis. This makes data derived from outcrop samples very difficult to interpret.

Macrofossils deposited in ancient deep-sea sediments that have not been uplifted on land usually have been subjected to only burial diagenesis, Extension of continentally derived fresh-water aquifers into marine sediments has only been recorded in near-continent hemipelagic sediments that have layers of permeable sandstone (Gieskes, 1981). From the interstitial water analyses performed on board ship, there is no evidence of fresh-water aquifer penetration into the pelagic sediments of Unit $\mathrm{V}$ at Site 603 (Site 603 chapter, this volume).

Very few studies have been conducted on macrofossils from deep sea cores. Only Barron et al. (1984) and Saltzman and Barron (1982) have reported oxygen isotope paleotemperatures from Inoceramus extracted from DSDP cores. After a rigorous selection procedure, Saltzman and Barron (1982) used only 49 specimens for determination of oxygen isotope paleotemperatures from an initial group of 500 Inoceramus specimens from DSDP cores. These 49 specimens-less than $10 \%$ of the total number of specimens-were deemed well preserved. Excellent preservation of Inoceramus specimens for paleotemperature determinations is not common in deep-sea core material.

In this study, Inoceramus, ammonite aptychi, a belemnite, and the host sediment have been analyzed for carbon and oxygen isotopes. Several types of macrofossils were chosen for isotopic analysis to see if the results from different taxa would yield distinctly different isotopic data.

\section{DISTRIBUTION OF MACROFOSSILS IN CORES FROM HOLE 603B}

A few fossil ammonites (Fig. 3A), as well as ammonite aptychi (Fig. 3B), Inoceramus, and shallow-water carbonate debris are incorporated in the sediment of Unit V. Table 1 lists the sample and the host lithology for each occurrence; the data are from the shipboard visual core descriptions and additional observations made by the author. Visual examination was limited to the two faces of the split core, therefore some macrofossil material may not have been detected.

The shallow-water carbonate debris is a minor to trace component contained within the terrigenous sandstone turbidites in Subunit VA. Some fragments of invertebrate remains that can be identified to the general taxa level are gastropods, pelecypods, and bryozoans (Biostratigraphy section in the Site 603 chapter, this volume). The other macroinvertebrate debris is usually shell fragments that are small and abraded, lacking characteristic features for additional identification. They do not appear to be fragments from delicate skeletal remains of aragonitic ammonites or calcareous Inoceramus shells. The carbonate debris is interpreted as being derived from shallow water because of the association with rare and poorly preserved shallow-water, midshelf benthic foraminifers (Biostratigraphy section in Site 603 chapter, this volume). The shallow-water skeletal debris and the abundant terrigenous clastics were transported from the shelf and redeposited in these turbidites associated with the submarine fan facies (see Sarti and von Rad, this volume, for a detailed discussion of the submarine fan facies). 
A

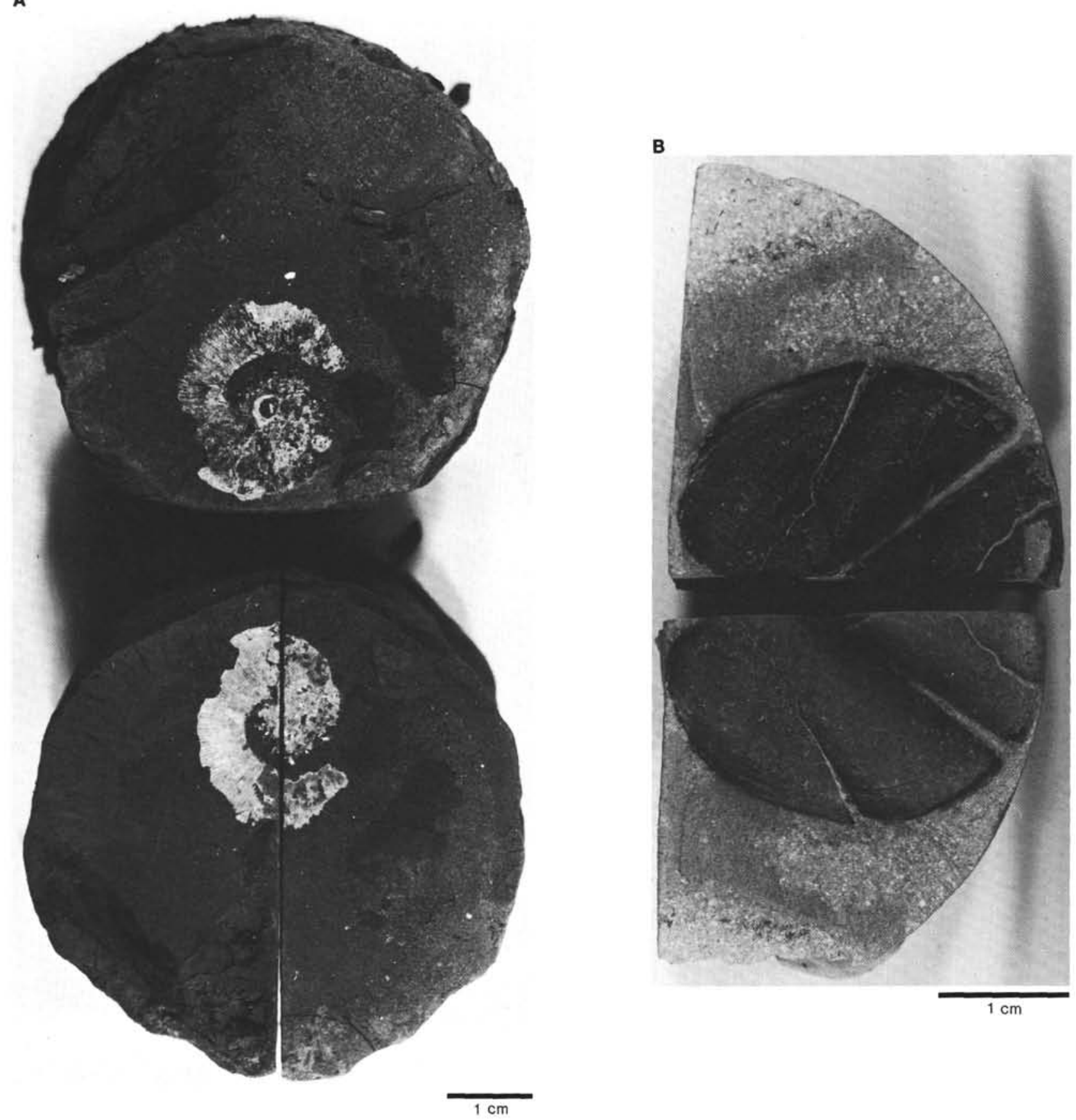

Figure 3. A. A Lower Cretaceous (Barremian-Aptian) ammonite on the bedding plane surface of the full-round of the core (Sample 603B-44-3, $140 \mathrm{~cm}$ ). See Frontispiece Figure D (this volume) for a color photograph of this ammonite, and Hoedemaker (this volume) for paleontologic details of the Lower Cretaceous ammonites. B. An aptychus found on the bedding plane of a quarter-round of the core. Upper and lower bedding plane surface shown. Note the dark chitinous layer on the surface of the aptychus. This sample (603B-79-2, $94.5 \mathrm{~cm}$ ) was found in the core shown in Figure 2.

The majority of the remaining macrofossils are impressions of flattened ammonites, calcite ammonite aptychi, or Inoceramus. These are predominantly found in the laminated limestone associated with Subunit VB (Fig. 2). A rare fragment of a belemnite (Fig. 4A) is also noted in the bioturbated limestone of Subunit VB. See Hoedemaker (this volume) for details on the taxonomy and biostratigraphic significance of the Early Cretaceous ammonites.

\section{METHODS}

After surveying the samples listed in Table 1, the author made a selection of samples that included Inoceramus, ammonite aptychi, and a portion of the belemnite rostrum fragment, as well as the host rock for isotopic analysis. No shallow-water carbonate debris were selected for analysis. DSDP policy does not permit researchers to decimate the core by splitting it on the bedding plane to find macrofossils or to determine the size or degree of preservation of the macrofossil fragments during investigations on board ship or at the core repository. Therefore, samples were chosen based upon examination of the cut face of 
Table 1. Distribution of macrofossils in cores from Hole 603B.

\begin{tabular}{|c|c|c|}
\hline $\begin{array}{l}\text { Core-Section, } \\
\text { interval or } \\
\text { level in cm }\end{array}$ & Lithology & Macrofossil \\
\hline $44-3,150$ & Laminated limestone & Ammonite \\
\hline $50-1,124-126$ & Laminated limestone & Inoceramus, aptychus \\
\hline $50-1,0-80$ & Sandstone & Shell debris \\
\hline $52-5,12-122$ & Sandstone & Shell debris \\
\hline $53-3,52-80$ & Sandstone & Shell debris \\
\hline $56-1,120-125$ & Sandstone & Shell debris \\
\hline $57-2,59-63$ & Sandstone & Shell debris \\
\hline $58-1$ & Laminated limestone & Aptychus \\
\hline $61-4$ & Laminated limestone & Aptychi \\
\hline $63-2,61-65$ & Bioturbated limestone & Inoceramus \\
\hline $63-3,10-20$ & Laminated limestone & Aptychus \\
\hline $69-5,15-20$ & Laminated limestone & Ammonite \\
\hline $75-3,113-117$ & Laminated limestone & Aptychi \\
\hline $75-3,131$ & Laminated limestone & Aptychus \\
\hline $76-1,120$ & Base of Subunit VA & \\
\hline $76-3,71$ & Laminated limestone & Aptychus \\
\hline $77-1,48-52$ & Bioturbated limestone & Belemnite \\
\hline $77-3,48-52$ & Laminated limestone & Inoceramus \\
\hline $78-1,51-52$ & Laminated limestone & Inoceramus, aptychi \\
\hline $78-2,94$ & Laminated limestone & Ammonite \\
\hline $78-2,110$ & Laminated limestone & Ammonite \\
\hline $78-3,65-66$ & Laminated limestone & Inoceramus \\
\hline $79-1,21$ & Laminated limestone & Aptychus \\
\hline $79-1,36$ & Laminated limestone & Aptychus \\
\hline $79-1,109$ & Laminated limestone & Aptychi \\
\hline $79-2,58-59$ & Laminated limestone & Aptychi \\
\hline $79-2,94$ & Laminated limestone & Aptychus \\
\hline $79-3,70-120$ & Laminated limestone & Aptychi \\
\hline $79-5$ & Laminated limestone & Aptychi \\
\hline $79-5,16-20$ & Laminated limestone & Aptychi \\
\hline $79-6,56-57$ & Laminated limestone & Inoceramus, aptychi \\
\hline $79-6,84-96$ & Laminated limestone & Aptychi, Inoceramus \\
\hline $80-1,6-7$ & Laminated limestone & Inoceramus, aptychi \\
\hline $80-2,125-130$ & Laminated limestone & Inoceramus \\
\hline $80-2,145-150$ & Laminated limestone & Inoceramus \\
\hline $80-3,20-21$ & Laminated limestone & Inoceramus \\
\hline $80-3,34-36$ & Laminated limestone & Inoceramus \\
\hline $80-4,60-65$ & Laminated limestone & Inoceramus \\
\hline $81-5,15-17$ & Laminated limestone & Inoceramus \\
\hline
\end{tabular}

the working half of the cores. (Sampling was not permitted of the archived half of the cores.) During shore-based studies, the samples were split along bedding planes to determine the size of the macrofossil fragments and to study the degree of alteration of the shell. Many of the fragments were too small for thin-section preparation with the host sediment. Thin sections containing the macrofossils and their immediate host rock were unsuitable for additional geochemical analysis by electron microprobe. The abundance of clay in the host rock made the thin-section preparation very difficult, and the sample could not be polished for quantitative microprobe analysis.

All hand specimens were examined with the use of a stereomicroscope for evidence of diagenesis. Subsamples of the carbonate shell were taken from the belemnite fragment, and aptychi fragments by breaking off pieces and carefully cleaning the exterior of any host sediment or organic chitinous coating (see Fig. 4B). Samples were taken from the calcite prismatic layer of Inoceramus fragments by breaking off pieces or by extracting individual crystals with a picking brush. Bulk rock samples of the host sediment were subsampled at the same time for isotopic analysis.

Samples were prepared for thin sectioning after they were subsampled for isotopic analysis. The rocks were pressure impregnated with epoxy resin and then cut and ground for thin section.

The macrofossil samples and the host rock samples for isotopic analysis were vacuum roasted at $350^{\circ} \mathrm{C}$ for an hour to remove volatile components. Carbon and oxygen stable isotopic compositions of the carbonate components of the bulk rock and of the macrofossils were measured by analyzing the carbon dioxide generated from the reaction of the samples with $100 \%$ phosphoric acid-a standard technique established by McCrea (1950). The carbon dioxide gas sample was ana-
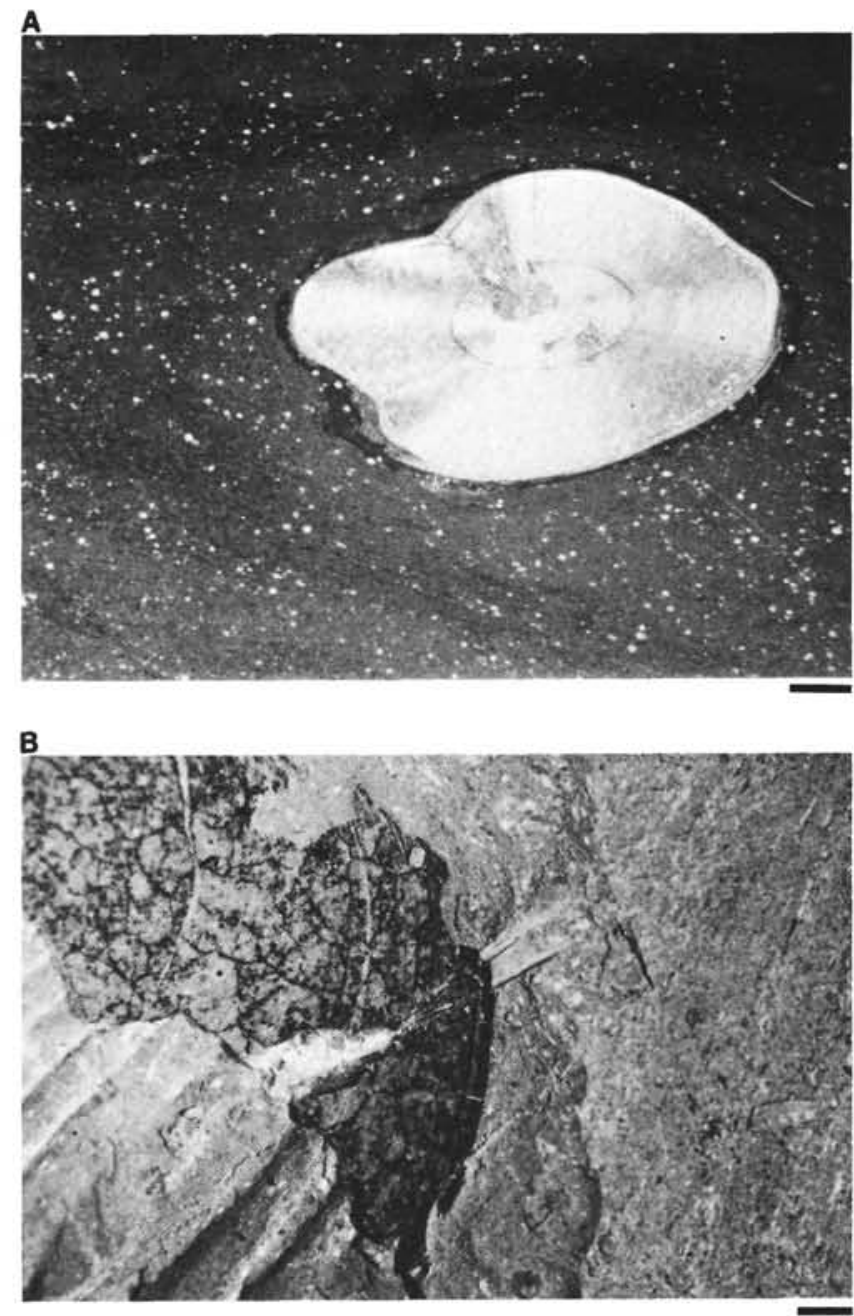

Figure 4. A. Photomicrograph (under crossed nicols; bar scale $=1 \mathrm{~mm}$ ) of a cross section of a belemnite in bioturbated limestone (Sample 603B-77-1, 48-52 cm). The belemnite has been infilled with sparry calcite but preservation of the shell is excellent; note the presence of pseudoisogyres in the shell. B. Chitinous organic coating on aptychus (Sample 603B-79-2, 58-59 cm; reflected light; bar scale = $1 \mathrm{~mm})$.

lyzed on a Finnigan MAT 251, an isotope ratio mass spectrometer. Analyses are reported relative to PDB (Pee Dee Belemnite) standard. Analytical error was no greater than $\pm 0.2 \%$.

The aptychi of the ammonites, the rostrum of the belemnite, and the prismatic layer of Inoceramus shells were originally composed of calcite (Majewske, 1974). Therefore, the remains of the pelagic macrofossils, and epibenthic Inoceramus were chosen for isotopic analysis because they are more likely to have survived diagenesis without recrystallization and isotopic re-equilibration. The purpose of analyzing the isotopic composition of these skeletal remains was to obtain the oxygen isotope paleotemperatures for the Early Cretaceous in the western North Atlantic. This approach to acquiring paleotemperatures is not new and has previously provided valuable information about deepsea circulation in the Late Cretaceous (Saltzman and Barron, 1982).

The estimation of paleotemperatures from the oxygen isotopic composition of the shell assumes that the shell was biogenically precipitated in isotopic equilibrium with the surrounding seawater when the organism was alive. Changes in the oxygen isotopic composition of the shell should therefore reflect changes in the temperature of the seawater, assuming no complications have arisen with glaciation or local differences in salinity. The original isotopic composition of the shell must be retained unaltered after the death of the organism for proper acquisition of an oxygen isotope paleotemperature. 


\section{J. A. HAGGERTY}

Many organisms do not necessarily precipitate their shells in isotopic equilibrium with the surrounding seawater, but impart a "vital effect" or shift in the oxygen isotopic signature of the shell (e.g., Weber and Woodhead, 1972). Yet several studies have analyzed the isotopic composition of Inoceramus and belemnites from Cretaceous epicontinental seas (Lowenstam and Epstein, 1954; Stevens and Clayton, 1971) and Inoceramus from deep-sea sediments (Barron et al., 1984, Saltzman and Barron, 1982) and assumed that the shells were secreted in isotopic equilibrium with the surrounding seawater. The oxygen isotopic composition of ammonite aptychi have not been previously reported in the literature for estimating paleotemperatures, and careful evaluation is required before assuming skeletal precipitation in isotopic equilibrium with seawater.

The method of calculating paleotemperatures of the Cretaceous seawater from the oxygen isotopic composition of Inoceramus that was employed by Saltzman and Barron (1982) is used in this study. This method makes use of an Epstein paleotemperature equation published by Yapp (1979):

$$
T\left({ }^{\circ} \mathrm{C}\right)=16.4-4.2\left(\delta_{\mathrm{c}}-\delta_{\mathrm{w}}\right)+0.13\left(\delta_{\mathrm{c}}-\delta_{\mathrm{w}}\right)^{2}
$$

where $\delta_{\mathrm{c}}=\delta^{18} \mathrm{O}$ (PDB) of the calcium carbonate, and $\delta_{\mathrm{w}}=\delta^{18} \mathrm{O}$ (SMOW) of the water.

The calculations performed in this study, and in Saltzman and Barron (1982), assume that the oxygen isotopic composition of mean ocean water during the Cretaceous was depleted by one per mil relative to the SMOW (Standard Mean Ocean Water) standard. This depletion of one per mil is used for the oxygen isotopic composition of seawater during the Cretaceous, because it is assumed that the polar ice volume was negligible during the Cretaceous (Shackleton and Kennett, 1975). The choice of this value for the water correction factor and this paleotemperature equation may be debated, but for the purposes of comparing data from this study with that of the Saltzman and Barron (1982) study, this value and paleotemperature equation are appropriate.

\section{RESULTS}

\section{Petrology}

The Blake-Bahama Formation correlates with Unit V at Site 603. This upper Berriasian to Aptian unit is composed of interbedded laminated limestone and bioturbated limestone with sandstone and claystone turbidites, and is divided into two subunits on the basis of the presence or absence of sandstone or claystone turbidites. The base of Subunit VA is placed at the base of the lowest claystone turbidite, Sample 603B-76-1, $120 \mathrm{~cm}$. The laminated limestone and the bioturbated limestone are very similar throughout the two subunits, and therefore the descriptions of the two rock types are representative of the whole unit. In the Site 603 chapter (this volume), the laminated limestone and the bioturbated limestone are frequently referred to as in situ pelagic sediments. This interpretation should be re-evaluated in light of the results of this study, which describe the variations and differences of the limestones at DSDP Site 603 .

The bioturbated and laminated limestones can be distinguished on the basis of their biologic sedimentary and depositional sedimentary structures. The two basic end members are distinctly laminated or bioturbated, but in several locations a transitional form is observed in which bioturbation has not completely destroyed the thin laminations (Fig. 5A). Any of these types of limestones may abut against an overlying turbidite (Fig. 5B). The percent of the core containing laminated limestones or marls increases from the bottom of Unit V to the base of Subunit VA where the claystone turbidites appear (see the core photos at the end of the Site 603 chapter, this vol-
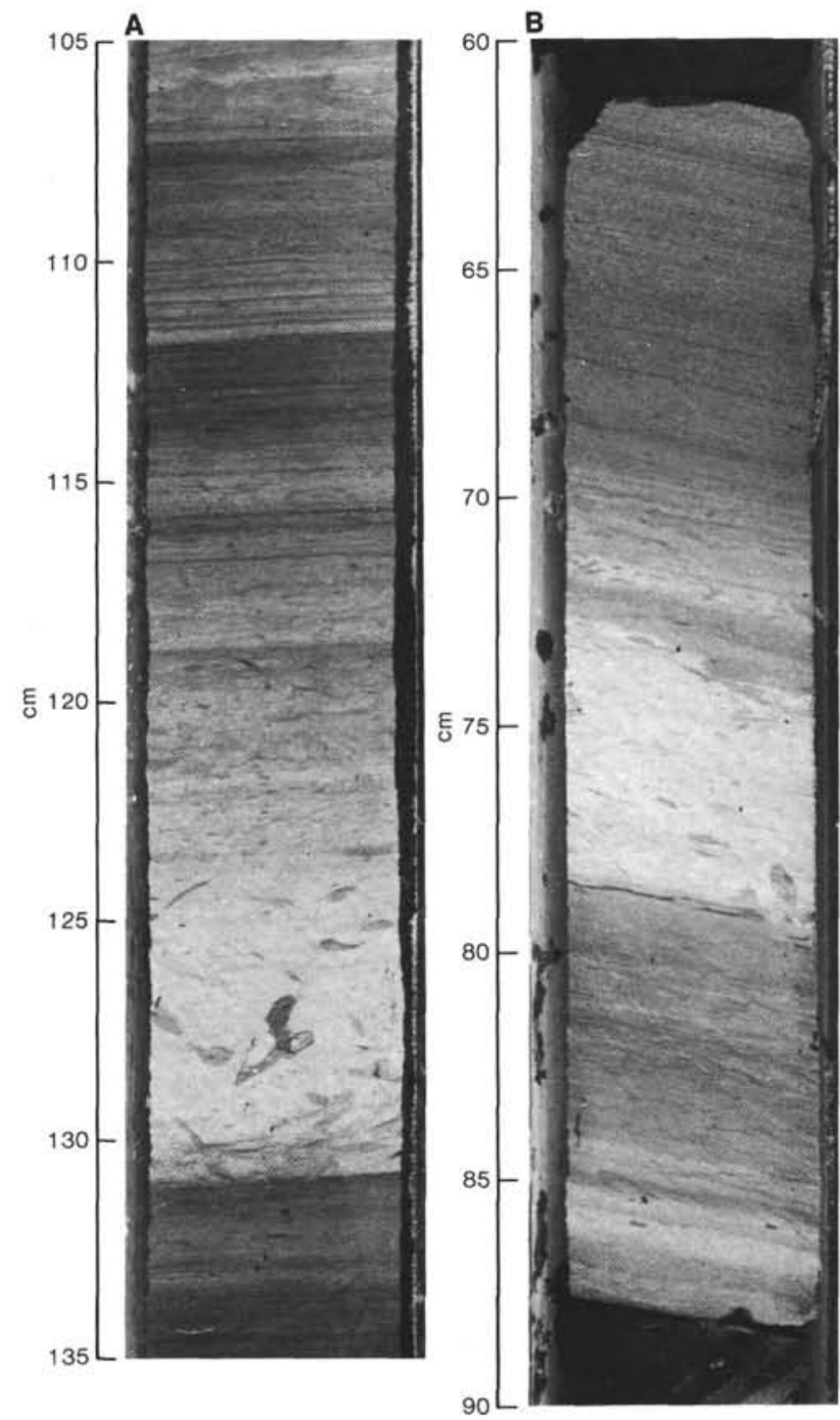

Figure 5. A. Bioturbated limestone interbedded with laminated limestone (Subunit VB, Sample 603B-74-4, 105-135 cm). Note the dark coloration of the clay-rich burrow fills. B. Typical laminated limestone and bioturbated limestone of the Blake-Bahama Formation found in Unit V at Site 603 (Sample 603B-70-3, 60-90 cm). Note areas in the cores that are an intermediate form, that is, indicating characteristics of bioturbation and faint lamination. This core is from Subunit VA and therefore contains deposits of turbidites, visible at the very upper and lower edges of the photographed interval.

ume). An inverse trend in the percent of core displaying evidence of bioturbation is also apparent in Subunit VB.

The variable amounts of clay, organic matter, and calcium carbonate contained within the limestones is directly related to their numerically assigned color using the Soil Color Charts of the Munsell Color Company. The darker colors (lower numbers) have a higher percentage of clay and/or organic matter, or a lower percentage of calcium carbonate. In some portions of the laminated lithology, the sediment is sufficiently clay rich to be termed a marl or marlstone (depending on degree of induration).

A comparison of the shipboard carbonate bomb data and organic carbon data of these three types of lime- 
stone-bioturbated, laminated, and transitional (laminated and bioturbated)-displays some interesting differences (see Table 2). The laminated limestone ranges in color from dark gray $(\mathrm{N} 2,5 \mathrm{Y} 2 / 1)$ to medium gray (N6, $5 \mathrm{Y} 6 / 1$ ) with a brownish tint, and has an average carbonate content of $68 \%$ and an organic carbon content of $1.41 \%$. The bioturbated limestone ranges in color from medium gray (N5) to nearly white (N8), and has an average carbonate content of $78 \%$ and an average organic carbon content of $0.19 \%$. The transitional limestone, which shows characteristics of being laminated and bioturbated, ranges in color from medium gray (N4) to light gray (N7), and has intermediate values of $69 \%$ for the average carbonate content and $0.33 \%$ for the average organic carbon content. The direction of the variations in the average carbonate and organic carbon content percentages agrees with the prediction based upon color of the sediment.

A significant trend that is suggested from the values listed in Table 2 is an increase in both the carbonate content and the organic carbon content from the lower Subunit VB to the upper Subunit VA of Hole 603B. There is a wide range and overlap in the values as shown by the standard deviation, but this trend is distinctly represented in the mean value for each of the three types of limestone. This trend is not a function of the color of the limestone because a detailed dissection of the data by color and type of limestone shows the same trend between Subunit VB and Subunit VA.

The bioturbated clay-rich nannofossil limestone contains abundant calcified or pyritized radiolarians. No Inoceramus fragments or ammonite aptychi have been found in this type of sediment. One belemnite fragment is found in Sample 603B-77-1, 48-52 cm (Fig. 4A). The bioturbation is detected in thin section by the patterns generated from either the increased concentrations of radiolarians within burrows and the patchiness of the micritic matrix (Fig. 6A) or by the color and textural difference of the increased clay content in a burrow (Fig. 5). Radiolarians, as well as burrows, are sometimes flattened and oriented parallel to bedding, therefore indicating compaction. Thin sections of some samples, denoted as bioturbated limestone in the Site 603 chapter (this volume), show layers that are enriched in radiolarians (Fig. 6B and C), but the hand samples display no color change indicative of a burrow. The enrichment of

Table 2. Carbonate and organic carbon content of "pelagic limestones" from Unit V of Hole 603B.

\begin{tabular}{lcccc}
\hline Texture & Subunit & $\begin{array}{c}\text { Carbonate } \\
(\%)\end{array}$ & $\begin{array}{c}\text { Organic carbon } \\
(\%)\end{array}$ & $\begin{array}{c}\text { No. of } \\
\text { analyses }\end{array}$ \\
\hline Laminated limestones & VA & $69 \pm 18$ & $1.44 \pm 0.6$ & 28 \\
& VB & $63 \pm 5$ & $1.27 \pm 0.5$ & 6 \\
& V & $68 \pm 17$ & $1.41 \pm 0.6$ & 34 \\
Bioturbated limestones & VA & $79 \pm 5$ & $0.21 \pm 0.1$ & 20 \\
& VB & $72 \pm 15$ & $0.07 \pm 0.07$ & 4 \\
& V & $78 \pm 8$ & $0.19 \pm 0.14$ & 24 \\
$\begin{array}{c}\text { Bioturbated and } \\
\text { laminated lime- } \\
\text { stones }\end{array}$ & VA & $70 \pm 8$ & $0.39 \pm 0.28$ & 13 \\
& VB & $65 \pm 10$ & $0.11 \pm 0.03$ & 3 \\
& V & $69 \pm 9$ & $0.33 \pm 0.27$ & 16 \\
\hline
\end{tabular}

radiolarians in these layers may be interpreted as the result of bioturbation concentrating the radiolarians without an increase in the clay and/or organic content of the burrow or as evidence of deposition associated with an increase in the supply of radiolarians or very weak current activity.

The ichnofabric in the bioturbated limestone displays a distinct decrease in burrow size from the bottom of the white limestone to the transitional bioturbated and laminated limestone (Figs. 5 and 7). This decrease in burrow size is easily observed because of the darker color of the burrow fill. Tiering relationships of the infauna are observed whereby Planolites is crosscut by Chondrites. Dark transitional limestone, with a laminated sedimentary fabric that contains evidence of bioturbation, is usually associated with very small-diameter burrows (Fig. 5); larger-diameter burrows are rarely observed in the dark transitional limestones unless they are within approximately $2 \mathrm{~cm}$ of an overlying light gray limestone.

The transitional form of a bioturbated, faintly laminated, clay-rich nannofossil limestone (Fig. 7A) may occur between two end members of bioturbated or laminated limestone, or one end member may not be present (Fig. 7B). Only one occurrence of a macrofossil in this type of transitional sediment is noted from Hole 603B (Sample 603B-81-5, 15-17 cm; Fig. 7A). Figures 6C, 8A, and $8 \mathrm{~B}$ show the sequence of change over an $8-\mathrm{cm}$ interval in Core 603B-75 from Subunit VB. Figure 6C is from bioturbated limestone in which radiolarians appear to be flattened from compaction. In Figure 8A the radiolarians are slightly concentrated in layers from current action. Figure 8B, which completes the sequence, shows that there has been a major decrease in the concentration of radiolarians and an increase in the clay content.

A microlenticular structure appears in the laminated limestone. The source of these lenticular structures may be diagenetic concentrations of silica and/or slight but significant changes in the constituent grains during deposition of the sediment. In thin section, these structures are resolved to be microlenticularlike bedding with single (isolated) lenses in what appears in hand specimen to be the distinctly laminated limestone (Fig. 9). The majority of these lenses are discontinuous and do not contain as much clay and organic debris as does the surrounding sediment. The lenses are exceptionally thin, giving a laminated appearance to hand samples of the rock. The outline of some lenses is enhanced by compaction of the clay and organic debris. The laminated limestone contains a terrigenous silt component of finegrained mica, and also land plant debris as exhibited by wood fragments. These lenses or laminations $(<1 \mathrm{~mm}$ in thickness) indicate that some bottom currents were active during deposition of the sediment. The appearance of the specimen is reminiscent of "Lithofacies G" of Mutti and Ricci Lucchi (1972).

The majority of the macrofossils found at Site 603 are deposited in the laminated sediment (Fig. 10). The degree of preservation of the macrofossils is variable. Some specimens are partially pyritized, others exhibit partial to complete recrystallization of the calcite, and others appear to be well preserved. 
A

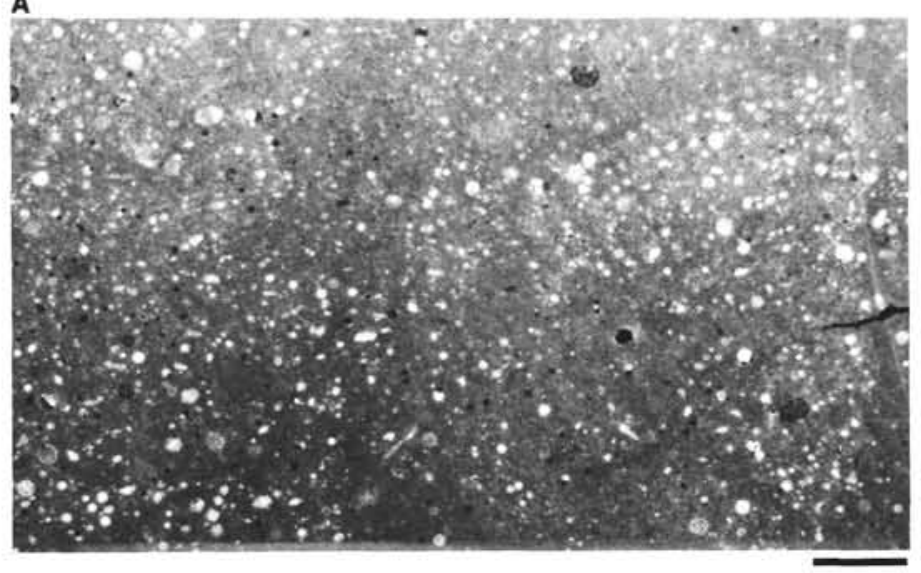

B

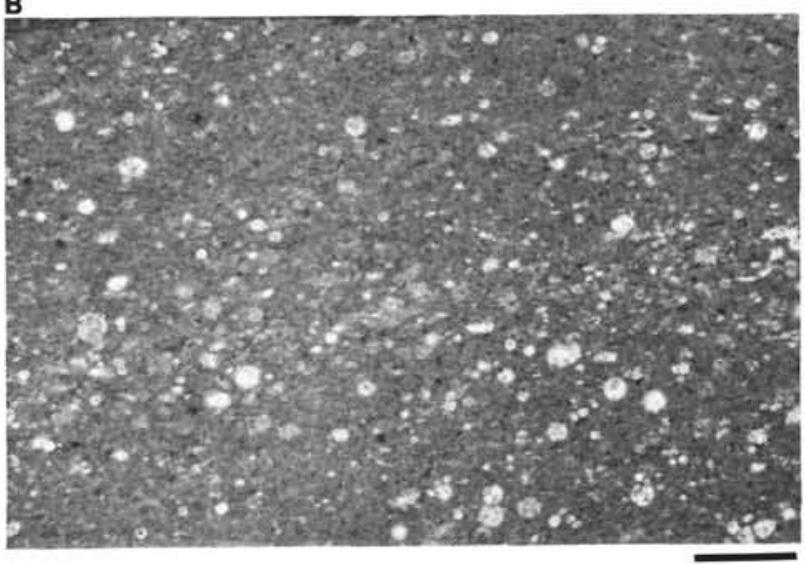

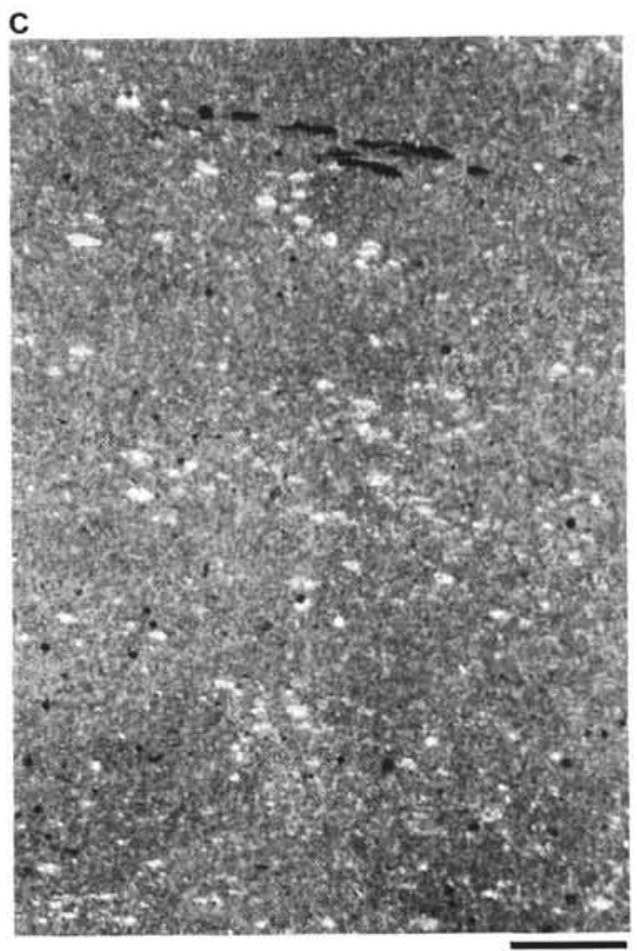

Figure 6. A. Bioturbated limestone of the Blake-Bahama Formation (Sample 603B-77-2, $42-46 \mathrm{~cm}$ ). Concentrations of calcified radiolarians are incorporated in burrow fills (plane polarized light; bar scale $=1 \mathrm{~mm}$ ). B. Bioturbated limestone containing a layer with abundant calcified radiolarians (Sample 603B-82-2,148-150 cm). These layers are probably the result of current activity winnowing away some of the fine clays and micrite (plane polarized light; bar scale $=0.5 \mathrm{~mm}$ ). C. Bioturbated limestone of the Blake-Bahama Formation $($ Sample $603 \mathrm{~B}-75-5,1-8 \mathrm{~cm}$ ) with patchy distribution of calcified and flattened radiolarians; flattening is probably the result of compaction (plane polarized light; bar scale = $0.5 \mathrm{~mm}$ ).

Close inspection of the contact between the macrofossils and the laminated sediment (Fig. 11) reveals no evidence of scouring activity around the fossil. Any distortion in the laminations appears to be the result of compaction of the soft sediment against the morphologic relief of the shell. On the basis of these observations, the currents that existed to develop the microlenticular bedding or laminations are interpreted to have been incapable of overturning or scouring around the macrofossils.

Inspection of one of the bedding planes in the distinctly laminated limestone-containing macrofossils (603B-
78-3, 65-66 cm) reveals disarticulated skeletal calcite prisms (Fig. 12A) associated with bioturbation (Fig. 12B) and boring of the shell (Fig. 12C). Mirror images of the top (Fig. 12D) and bottom (Fig. 12E) bedding planes show that boring of the shell by infaunal organisms scattered the prisms in the immediate overlying sediment. The existence of infaunal organisms are evidence of at least a moderately oxygenated environment.

Radiolarians are not abundant in the laminated sediment. Foraminifers are very rare and have a sporadic occurrence in these laminated sediments. The low diversity of foraminiferal assemblages and the small size of the 
A

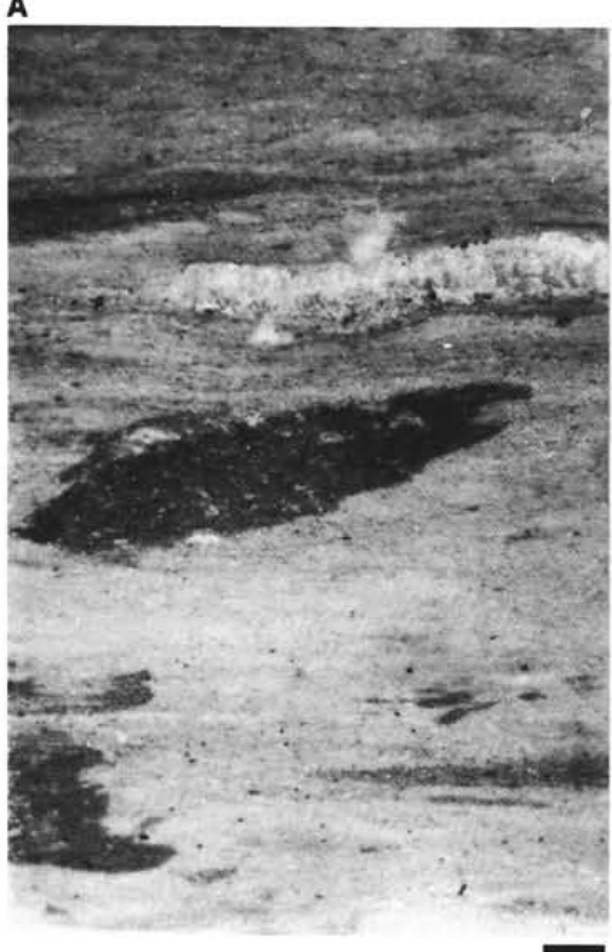

B

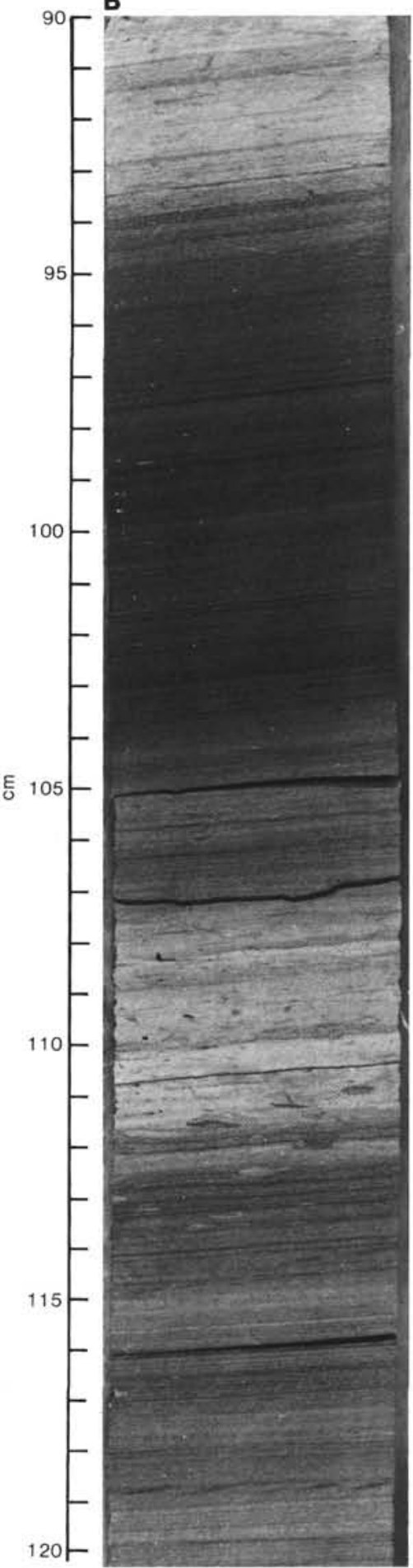

Figure 7. A. Transitional limestone (Sample 603B-81-5, 15-17 cm); bioturbation has not destroyed faint laminations. Note the rare occurrence of a shell from a macrofossil incorporated in the bioturbated sediment; the burrow is slightly flattened from compaction. Also note the dark clay-rich infilling of the burrow (reflected light; bar scale $=1 \mathrm{~mm}$ ). B. Transitional limestone (with characteristics of bioturbation and faint lamination), associated with two cycles of laminated limestone (Sample 603B-81-2, $90-120 \mathrm{~cm}$ ). Note that flattening of the dark burrows enhances the appearance of the laminations.

benthic foraminifers is suggested to be indicative of a deep-water calcareous and agglutinated assemblage that may have been transported from their original biotope (Biostratigraphy section in the Site 603 chapter, this volume). The calcium carbonate content (see Table 2) and the darker coloration of the sediment in comparison to the bioturbated limestone suggest that nannofossils are probably not as abundant as in the latter. The combination of the above-described observations of (1) the existence of infaunal organisms, accompanied by (2) a de- 
A

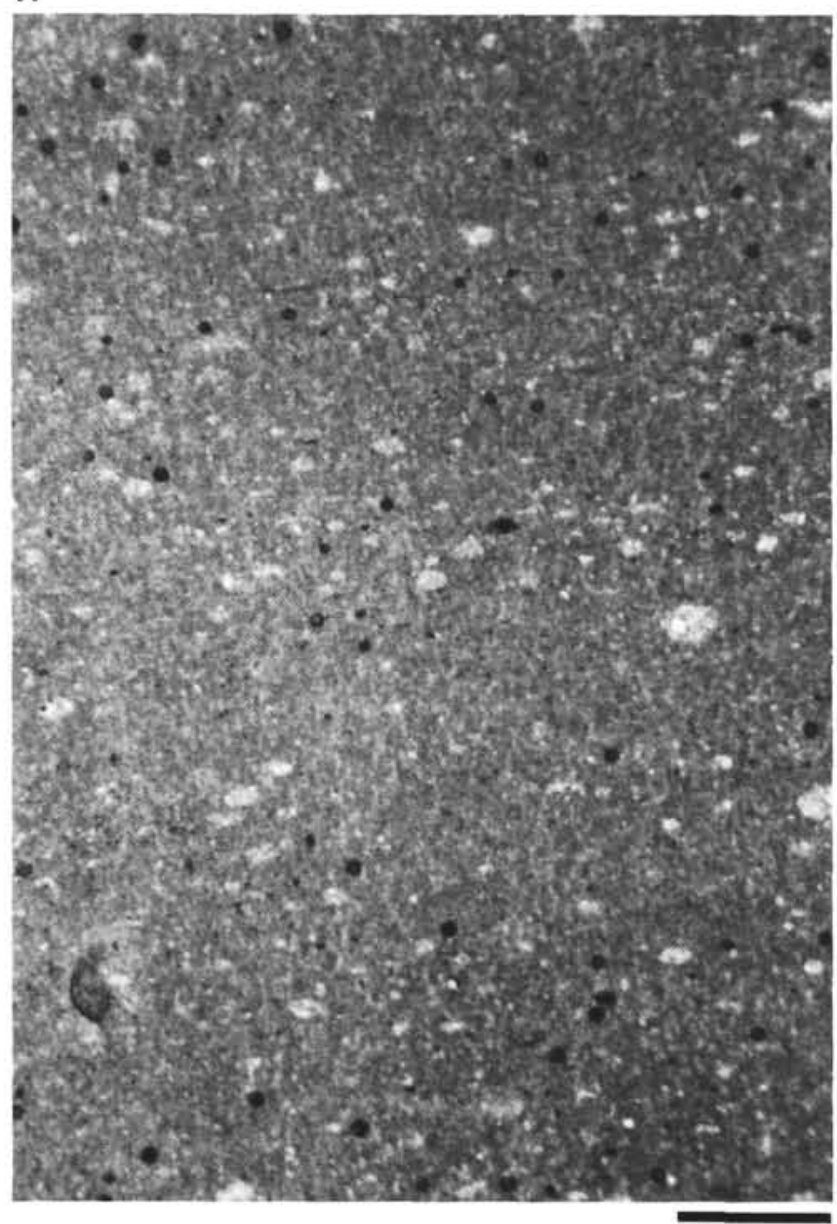

B

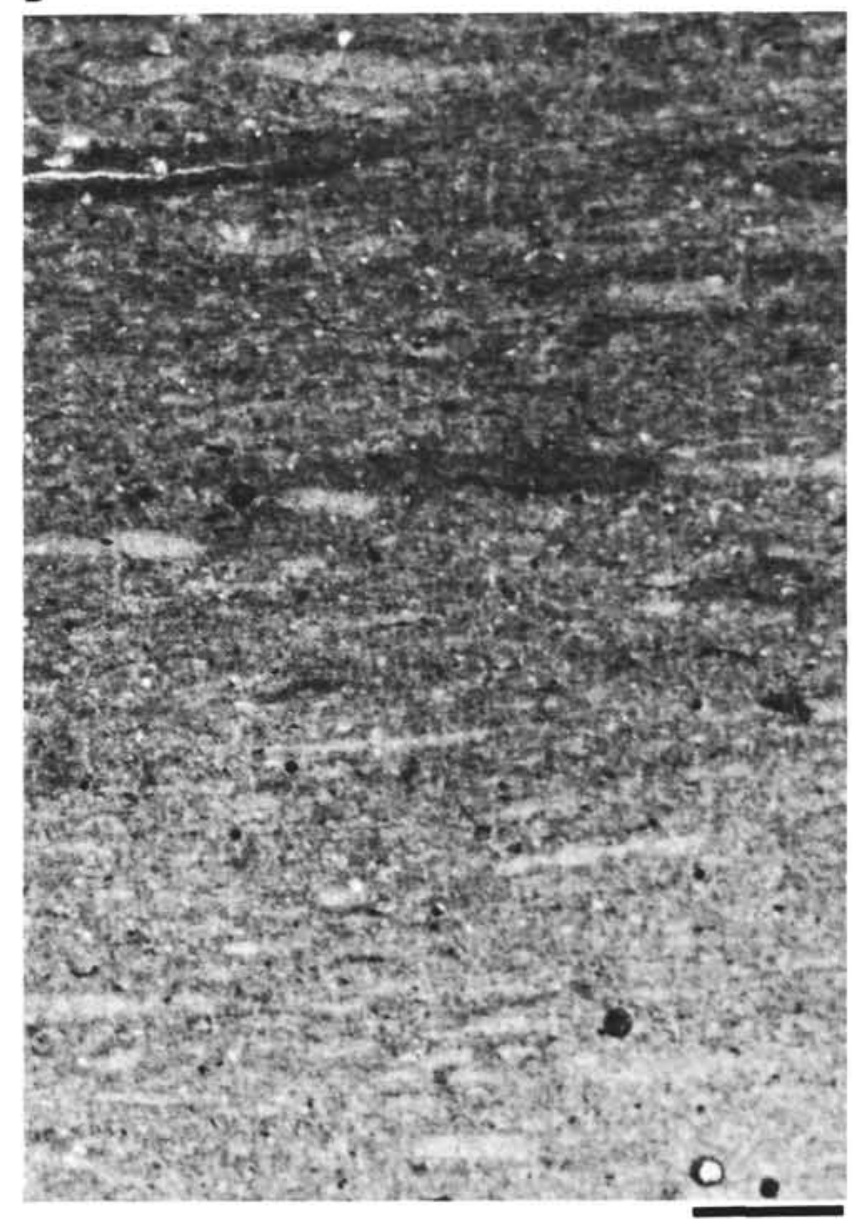

Figure 8. A. Second in a series displaying the transition from bioturbated limestone to laminated limestone in the Blake-Bahama Formation (Sample 603B-75-5, 1-8 cm). (Fig. 6C is the first in the series.) The distribution of radiolarians is concentrated into layers, and their abundance is decreasing (plane polarized light; bar scale $=0.5 \mathrm{~mm}$ ). B. The last of a series displaying the transition from bioturbated limestone to laminated limestone (Sample 603B-75-5, 1-8 cm). (The previous two photographs in the sequence are Figs. 6C and 8A.) The transition is marked by the change in color and appearance of microlenticularlike structures (plane polarized light; bar scale $=0.5 \mathrm{~mm}$ ).

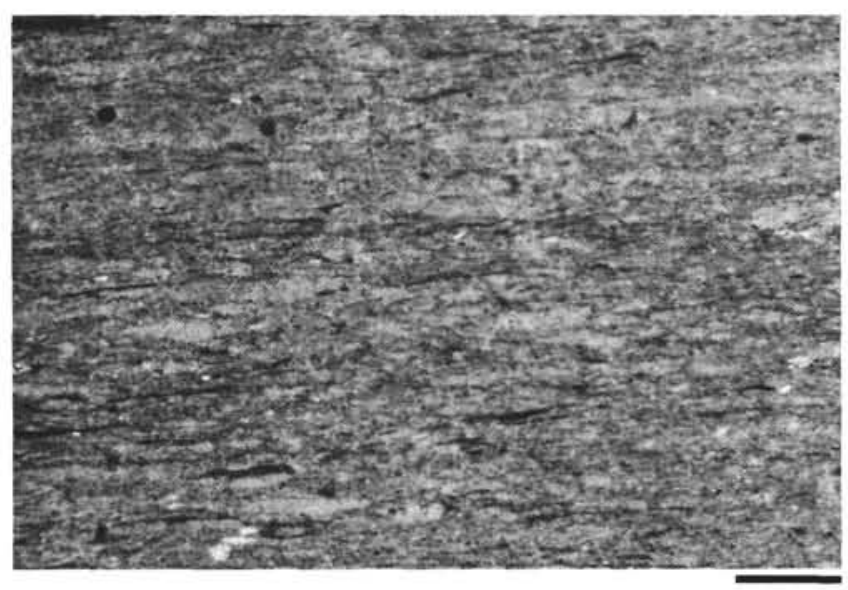

Figure 9. Laminated limestone from Blake-Bahama Formation at Site 603 , which contains microlenticularlike structures whose outline is enhanced by compaction of surrounding clays (Sample 603B-77-3, $48-52 \mathrm{~cm}$ ). The lenses may be a product of diagenesis but probably are related to a difference in the original sediment that was deposited (plane polarized light; bar scale $=0.5 \mathrm{~mm}$ ). crease in bioturbation activity and burrow size, as well as (3) an increase in terrigenous clastic components, and (4) a decrease in the abundance of microfossils in the laminated sediments indicates that the rate of deposition of the laminated sediments may have been greater than that of the bioturbated limestone. The laminated strata are not interpreted as an anaerobic facies because of the presence of epibenthic macrofossils and evidence of infaunal activity.

\section{Stable Isotopes}

Table 3 lists the type of macrofossil, the stable isotopic composition of the macrofossil, and that of the host rock. The lithology of the host rock for all of the Inoceramus and aptychi listed in Table 3 is laminated limestone; only the belemnite was contained in bioturbated limestone. This table also contains data for additional samples of limestone from Prezbindowski and Pittman (this volume); their samples of limestone were pretreated by the same method as the samples in this study and were analyzed in the same laboratory. Therefore, it is reasonable to combine the two data sets. 


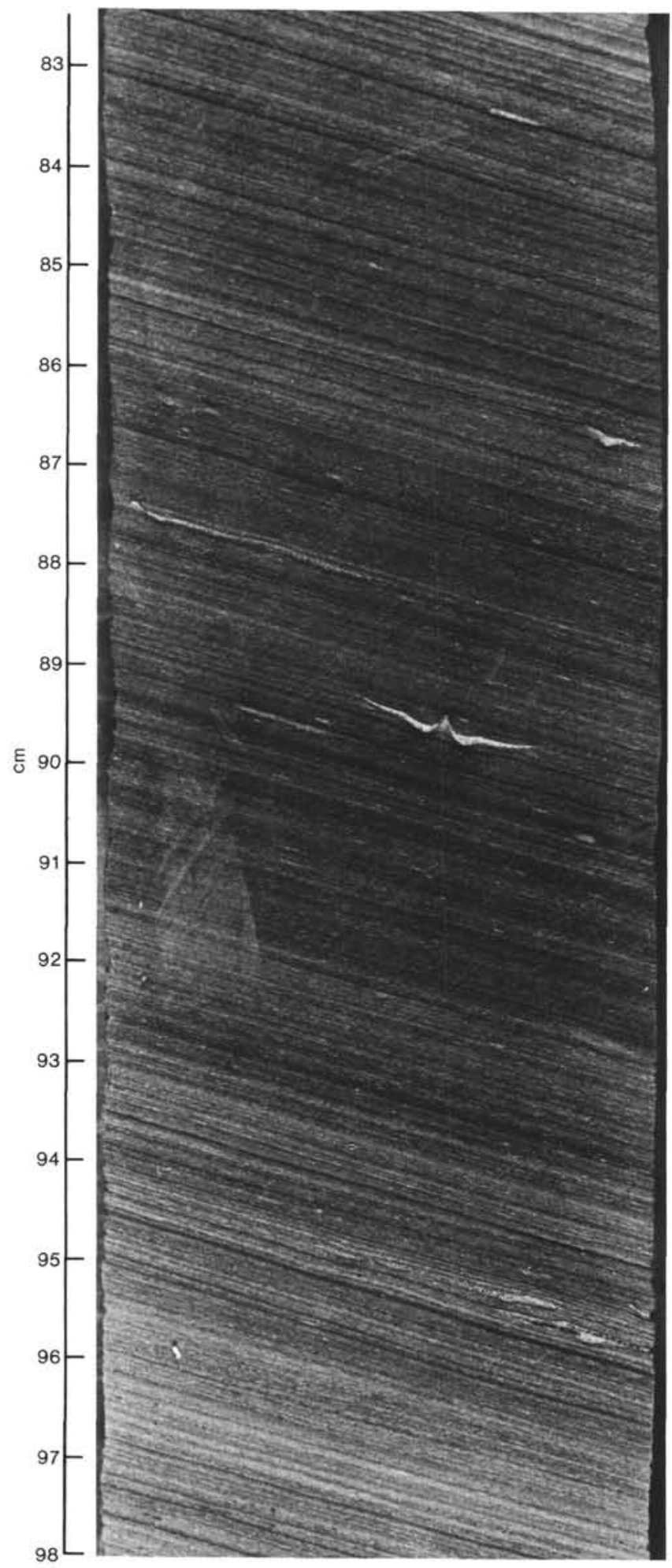

Figure 10. Cut surface of core displaying fragments of aptychi and Inoceramus contained in the laminated limestone (Sample 603B$79-6,83-98 \mathrm{~cm}$ ). (Close-up of core shown in Figure 2.) Note the orientation of the aptychus located at $90 \mathrm{~cm}$.

Figure 13 is a cross plot of the data listed in Table 3. The plot shows a scatter of points from all lithologies and macrofossils. There does not appear to be any trend with increasing sub-bottom depth. Two statements can

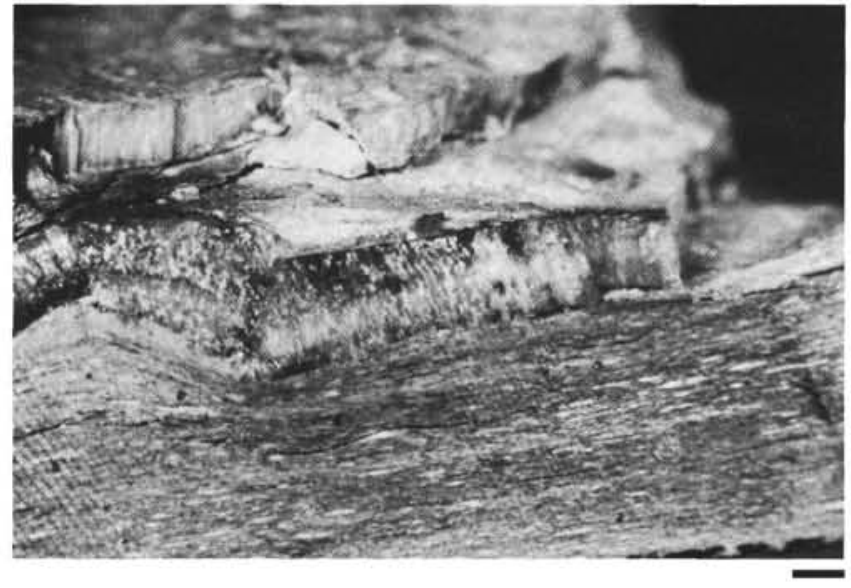

Figure 11. Laminated limestone with macrofossil (Sample 603B-78-1, $51-52 \mathrm{~cm})$. There is no evidence of current scouring around the fossil; the only distortion of the laminations is from compaction of sediment (reflected light; bar scale $=1 \mathrm{~mm}$ ).

be made from an evaluation of this plot. The aptychi are significantly depleted in both ${ }^{13} \mathrm{C}$ and ${ }^{18} \mathrm{O}$ by comparison with the other in samples, and the bioturbated limestone also appears to be slightly depleted in ${ }^{18} \mathrm{O}$ relative to the laminated limestone and Inoceramus fragments. No definitive statements can be made as to whether there is a pronounced enrichment in ${ }^{13} \mathrm{C}$ in either the bioturbated or laminated limestones or even if there is an enrichment in ${ }^{13} \mathrm{C}$ in the limestones from Subunit VA to those of Subunit VB.

\section{Diagenetic Trends}

In order to evaluate the effect of diagenesis on the isotopic composition of Inoceramus, two specimens (Samples $603 \mathrm{~B}-78-1,51-58 \mathrm{~cm}$ and $603 \mathrm{~B}-80-3,20-21 \mathrm{~cm}$ ) that clearly exhibited the effects of recrystallization in the prismatic layer were analyzed. Sample 603B-80-3, 20-21 $\mathrm{cm}$ had more than one specimen of Inoceramus available for subsampling; one of these specimens displayed a cloudy white coloration in the prisms, indicating that recrystallization had occurred. The two specimens that distinctly exhibited diagenetic alteration yielded values that were depleted in ${ }^{18} \mathrm{O}(-3.3$ and $-3.5 \%)$ and ${ }^{13} \mathrm{C}$ $(-0.3$ and $0.2 \% 0$ ) relative to the isotopic composition of the well-preserved specimen from Sample 603B-80-3, $20-21 \mathrm{~cm}$ (see Table 3). Barron et al. (1984) reported values as light as $-6.75 \%_{0}$ in $\delta^{18} \mathrm{O}$ and $-3.2 \%_{0}$ in $\delta^{13} \mathrm{C}$ for poorly preserved Inoceramus specimens from Upper Cretaceous strata in Hole 530A in the Angola Basin of the South Atlantic. In the study by Saltzman and Barron (1982), the isotopic values obtained from well-preserved Late Cretaceous specimens ranged from -2.41 to +1.88 for $\delta^{18} \mathrm{O}$ and -1.27 to +3.01 for $\delta^{13} \mathrm{C}$.

The $90 \%$ rejection rate of Inoceramus specimens in the Saltzman and Barron (1982) study and the observed variability in the oxygen isotopic composition of the Inoceramus specimens listed in Table 3 encourage caution in the interpretation of paleotemperatures derived from oxygen isotopic compositions. Some of the Inoceramus samples may have diagenetic alterations that were not 


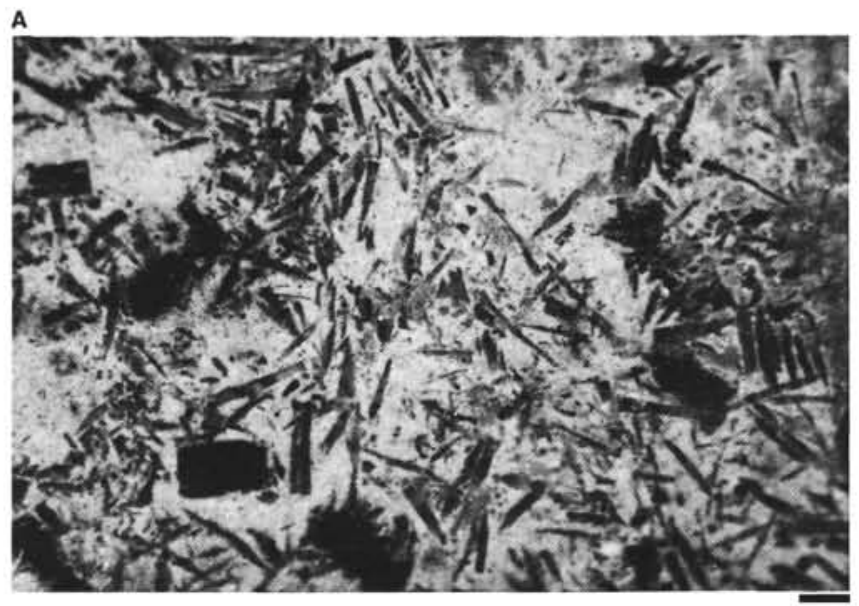

B

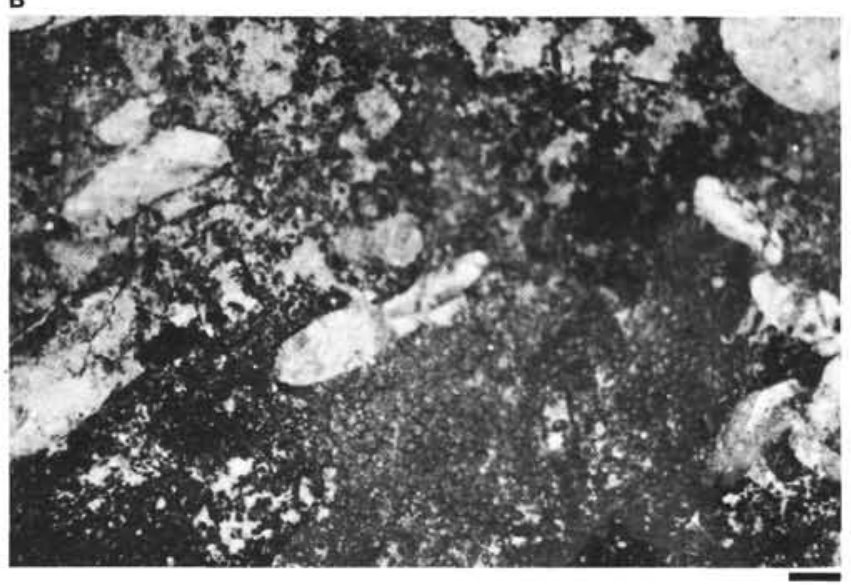

D

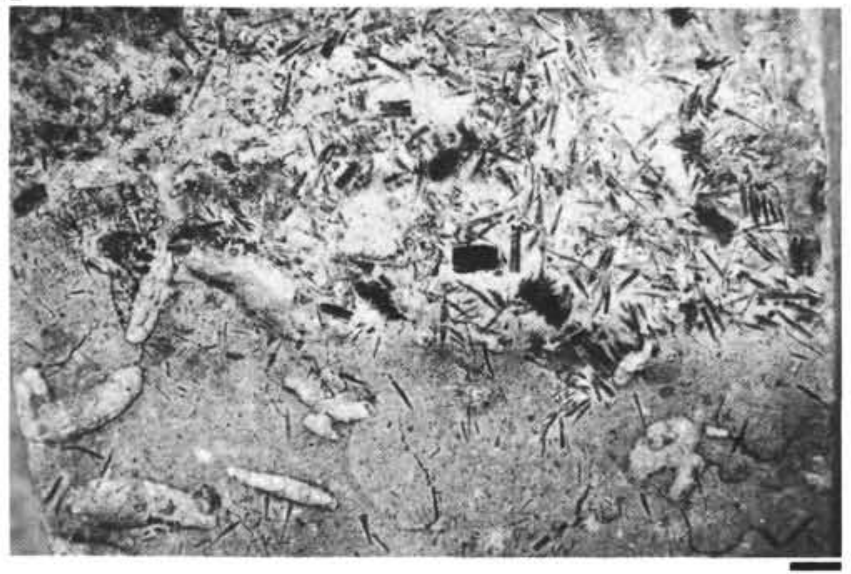

C

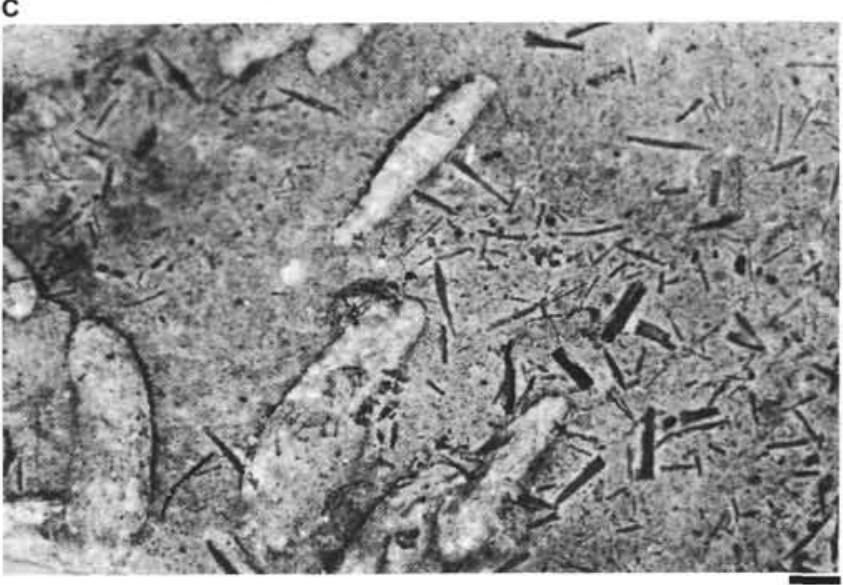

E

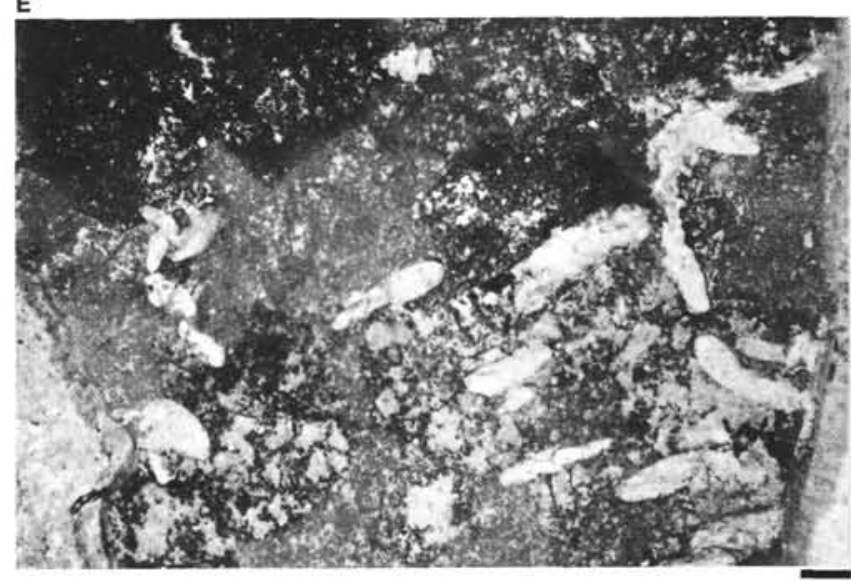

Figure 12. A. Scattered skeletal calcite prisms in laminated limestone (Sample 603B-78-3, 65-66 cm) (reflected light; bar scale $=0.5 \mathrm{~mm})$. B. Borings by infaunal organism into macrofossil shell in sediment (Sample 603B-78-3, 65-66 cm; lower bedding plane) (reflected light; bar scale = $0.5 \mathrm{~mm}$ ). C. Infilling of borings on upper bedding plane surface from the sample viewed in Figure 12B (Sample 603B-78-3, 65-66 cm) (reflected light; bar scale $=0.5 \mathrm{~mm}$ ). D and E. Mirror images of the upper and lower bedding plane surface showing evidence of boring and bioturbation by infaunal organisms. (Sample 603B-78-3, 65-66 cm) (reflected light; bar scale $=1 \mathrm{~mm}$ ).

detected by microscope evaluation of the hand specimen. This author recommends against the use of data from specimens that have oxygen isotopic compositions more negative than the host rock value and that also have relatively depleted carbon isotopic signatures.

The reason for discounting oxygen isotopic compositions that have values more negative than the host rock value is that such negative values suggest a diagenetic reequilibration has occurred. Diagenesis may have taken place later in the burial history of the sediment associated with warmer temperatures or the isotopic composition of the shells and sediment may also be altered by waters depleted in ${ }^{18} \mathrm{O}$ from clay mineral diagenesis or basalt alteration. Diagenesis during burial or interaction 
Table 3. Stable isotope analyses of macrofossils and host rock from Unit V of Hole 603B.

\begin{tabular}{|c|c|c|c|c|c|}
\hline \multirow{2}{*}{$\begin{array}{l}\text { Core-Section, } \\
\text { interval or } \\
\text { level in } \mathrm{cm}\end{array}$} & \multirow{2}{*}{$\begin{array}{c}\text { Type of rock } \\
\text { or macrofossil }^{\mathrm{a}}\end{array}$} & \multicolumn{2}{|c|}{ Host rock } & \multicolumn{2}{|c|}{ Macrofossil } \\
\hline & & $\delta^{13} \mathrm{C}$ & $\delta^{18} \mathrm{O}$ & $\delta^{13} \mathrm{C}$ & $\delta^{18} \mathrm{O}$ \\
\hline $50-1,124-126$ & Inoceramus & -0.4 & -2.7 & +0.4 & $-2.1^{\mathrm{d}}$ \\
\hline $53-1,51-55 \mathrm{~b}$ & Laminated limestone & -0.3 & -3.7 & & \\
\hline $61-1,86-91^{b}$ & Bioturbated limestone & -0.1 & -4.4 & & \\
\hline $62-2,50-56^{\mathrm{b}}$ & Bioturbated limestone & +0.2 & -4.5 & & \\
\hline $62-2,56-57^{b}$ & Bioturbated limestone & +0.2 & -4.2 & & \\
\hline $63-2,61-65$ & Inoceramus & & & +0.5 & -4.0 \\
\hline $76-1,120$ & Base of Subunit VA & & & & \\
\hline $77-1,48-52$ & Belemnite & +0.8 & -4.1 & +0.4 & $+0.2^{\mathrm{d}}$ \\
\hline $78-1,51-52$ & Inoceramus & +1.2 & -3.0 & $-0.3^{c}$ & $-3.3^{\mathrm{c}}$ \\
\hline $78-3,65-66$ & Inoceramus & +0.8 & -2.2 & -2.1 & -2.5 \\
\hline $79-1,109$ & Aptychus & +0.8 & -1.9 & -0.1 & -7.8 \\
\hline $79-1,110$ & Bioturbated limestone & -0.7 & -3.9 & & \\
\hline $79-2,58-59$ & Aptychus & +0.9 & -2.3 & -1.2 & -4.7 \\
\hline $79-6,56-57$ & Inoceramus & -0.4 & -2.7 & +0.9 & $-2.4^{\mathrm{d}}$ \\
\hline $80-1,6-7$ & Inoceramus & +1.0 & -2.4 & -0.7 & -3.2 \\
\hline $80-3,20-21$ & Inoceramus & +0.3 & -2.3 & $-0.2^{\mathrm{c}}$ & $-3.5^{\mathrm{c}}$ \\
\hline & Inoceramus & & & +1.7 & $-0.7^{\mathrm{d}}$ \\
\hline $81-5,15-17$ & Inoceramus & -0.4 & -3.5 & +0.9 & $-2.7^{\mathrm{d}}$ \\
\hline
\end{tabular}

a See Table 1 for the type of host lithology containing the macrofossil.

b Data from Prezbindowski and Pittman (this volume).

c Hand samples that show distinct evidence of recrystallization.

d Reliable samples for paleotemperature determination.

with fresh water will deplete the ${ }^{18} \mathrm{O}$ content of the carbonate. The host rock at Site 603 is diagenetically altered (Prezbindowski and Pittman, this volume), and therefore it is possible that the macrofossils have also been altered.
After the criterion for the oxygen isotopic composition is met, the sample should be evaluated by a second criterion based on the carbon isotopic composition. Depletion of ${ }^{13} \mathrm{C}$ in carbonates commonly results from the incorporation of isotopically light carbon derived from the diagenesis of organic matter. Usually the more negative the $\delta^{13} \mathrm{C}$ composition of the sediment, the greater the contribution from organic matter.

Use of the above two guidelines eliminates the two samples of Inoceramus that visually showed evidence of recrystallization for use in paleotemperature determination. Of the remaining seven specimens of Inoceramus that were analyzed, three of these specimens are also eliminated by the above criteria. This may be considered a conservative approach, but most workers (e.g., Stevens and Clayton, 1971) have assumed that the lowest temperature calculated for a sample, locality, or time span yields the lowest probability of having undergone diagenetic alteration and therefore is closest to the correct value. The specimens that are eliminated for paleotemperature consideration will typically yield higher oxygen isotope paleotemperatures than the remaining "reliable" specimens.

The oxygen stable isotopic composition of the aptychi are very depleted in ${ }^{18} \mathrm{O}$. According to Lehmann (1979), well-preserved aptychi have a thin, dark layer of horny or chitinous material covering the innermost calcite layer. Many of the aptychi in these cores exhibited a dark layer coating the surface (Fig. 3B). The specimens chosen for isotopic analysis had a dark coating that was

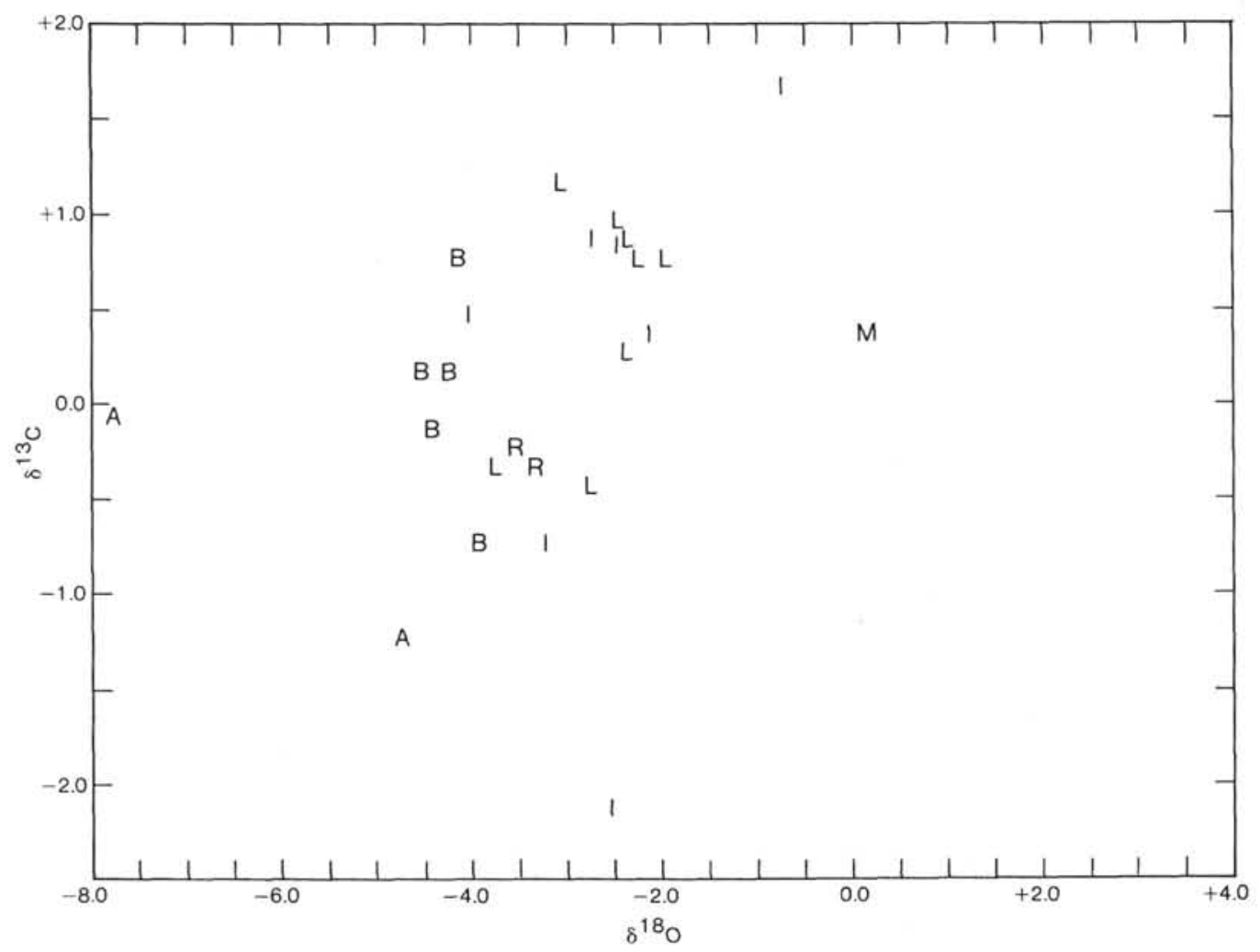

Figure 13. Cross plot of $\delta^{13} \mathrm{C}$ and $\delta^{18} \mathrm{O}$ analyses listed in Table 3. The symbols indicate the lithology of the host rock samples, as well as the type of macrofossil fragment analyzed: $\mathrm{B}=$ bioturbated limestone, $\mathrm{L}=$ laminated limestone, $\mathrm{R}=$ visibly recrystallized Inoceramus, $\mathrm{I}=$ Inoceramus, $\mathrm{A}=$ aptychi, and $\mathrm{M}=$ belemnite. 
not pyritized (Fig. 4B). The host sediment has undergone diagenesis, as exhibited by replacement of the radiolarian tests with ferroan calcite, and partial dissolution of the coccoliths (Prezbindowski and Pittman, this volume), but the depletion of ${ }^{18} \mathrm{O}$ in the ammonite aptychi may not be completely the result of diagenetic re-equilibration within the sediment.

If one compares the isotopic values of the host rock with those of the aptychi, the isotopic values of the aptychi are significantly depleted. If the aptychi had diagenetically re-equilibrated with the host sediment, one would expect the oxygen isotope values to shift toward the host rock values. The oxygen isotopic composition of the aptychi may indicate a diagenetic re-equilibration at a later, warmer time in the burial history of the sediment. Another possible explanation that should be considered is that the initial oxygen isotopic composition of the aptychi may reflect a "vital effect" fractionation by the living organism. If this is the case, the isotopic composition of the aptychi was never in isotopic equilibrium with Cretaceous seawater.

The carbon isotopic signature provides another clue that the aptychi may have undergone some diagenetic alteration or are exhibiting additional complications from biologic fractionation of the isotopes. Both of the specimens have negative carbon isotopic signatures. Alteration or a slight deterioration of the chitinous organic layer that was originally in contact with the aptychi may have contributed to the negative carbon isotopic signature of the calcite aptychi. A similar depleted carbon isotopic signature is seen in the visibly recrystallized samples of Inoceramus. The two specimens have a negative carbon isotopic signature, whereas most of the Inoceramus specimens that were not suspected of being diagenetically altered have a positive carbon isotopic signature.

\section{Paleotemperature Results}

The Inoceramus specimens exhibit a wide range of variability in their isotopic composition. The specimens from Subunit VB have an average value of $-1.3 \%$ for $\delta^{18} \mathrm{O}$ and the host rock has an average value of $-2.6 \%$ for $\delta^{18} \mathrm{O}$. The average value of $-1.7 \%$ for $\delta^{18} \mathrm{O}$ is obtained for all the Inoceramus specimens analyzed in Unit $\mathrm{V}$ (excluding the two specimens noted earlier as having been recrystallized), whereas the laminated limestone host rock of Unit $\mathrm{V}$ has an average value of $-2.8 \%$ for $\delta^{18} \mathrm{O}$. The oxygen isotopic composition of the Inoceramus does not appear to be in equilibrium with the host rock.

The isotopic composition of four of the seven Inoceramus specimens listed in Table 3 (the specimens that visually showed no sign of diagenetic alteration) is consistent with the two evaluating criteria discussed in the Diagenetic Trends section. The calculated oxygen isotope paleotemperatures of three of these samples indicate warm bottom-water temperatures of about 21 to $23^{\circ} \mathrm{C}$, the fourth gives a value of about $15^{\circ} \mathrm{C}$.

Sample 603B-80-3, 20-21 cm, which was not visually suspected of being recrystallized, has the strongest positive carbon isotopic signature of all the specimens, and an oxygen isotope composition of $-0.7 \%$, which is enriched in ${ }^{18} \mathrm{O}$ relative to the host rock. This oxygen iso- tope value yields a warm, but more reasonable, bottomwater temperature of about $15^{\circ} \mathrm{C}$. The assumption that the lowest temperature calculated for a sample, locality, or time span yields the lowest probability of having undergone diagenetic alteration and therefore is closest to the correct value may indicate that this is the "most reliable" Inoceramus specimen and oxygen isotope paleotemperature. This calculated temperature is in good agreement with the belemnite sample (Sample 603B-77-1, 48$52 \mathrm{~cm}$ ), which yields an oxygen isotope paleotemperature of approximately $11^{\circ} \mathrm{C}$.

The belemnite shell has not undergone recrystallization of the calcite rostrum. This was verified by observation of the thin section under crossed nicols on a petrographic microscrope (Fig. 4A). The coarse texture of sparry calcite is observed as an infilling within the rostrum, but no sparry calcite is observed within the cross section of the rostrum. The pseudoisogyres that extend through the rostrum are also visible under crossed nicols. This feature is additional evidence that the microstructure is not disturbed and that this belemnite is not recrystallized. The oxygen isotopic composition of the belemnite is probably indicative of the initial composition of the shell. The author interprets the oxygen isotope paleotemperature derived from the isotopic value of the belemnite to be an appropriate indicator of the temperature of the water in the Early Cretaceous North Atlantic Ocean.

If the carbon isotopic compositions of the four "reliable" Inoceramus samples are evaluated, those contained in. Subunit VB are enriched in ${ }^{13} \mathrm{C}$ (mean $\left.=+1.2\right)$, compared to those in Subunit VA $(+0.4)$. Many times such signals, which may be interpreted as climatic, cannot be unraveled from the sediment because of variable compositions of the sediment components contributing to the isotopic signature. The Inoceramus should respond as a biologic indicator because the shell should have incorporated the isotopic signature from the water column. The small number of samples does not permit a distinction as to whether this shift is significant or even reliable. From the oxygen isotopic composition of the four "reliable" Inoceramus fragments there does not appear to be any distinct trend through time. The question of changes in the bottom-water temperature from the late Berriasian to the Aptian cannot be addressed with such few samples. These questions could be answered if a sufficient number of unaltered Inoceramus samples were run and compared with the host sediment. From the data listed in Table 3, there does not appear to be any definite trends. Additional analyses need to be made to consider these points.

\section{DISCUSSION}

The increase in clay content in the laminated limestone compared to the clay content in the bioturbated limestone is interpreted as the result of an increase in terrigenous sediment input. The laminated limestone contains marine organic material as well as abundant terrestrial organic material (Organic Geochemistry section in Site 603 chapter; Dunham et al., this volume). The periodic influx of clay, very fine grained sand, and terrige- 
nous organic matter is interpreted to have resulted in the interbedded nature of the laminated limestone with the bioturbated limestone at Site 603 .

Careful review of the percent of the core containing intervals of laminated limestone versus the other lithologic types reveals an increase in the laminated limestone or marl from the bottom of Unit V to the base of Subunit VA where the claystone turbidites appear. These intervals of laminated limestone anteceded the claystone turbidites and perhaps indicate the progradation of the Tithonian-Barremian deltas (Jansa et al., 1979) that developed on the inner and middle continental shelf. Not until the deposition of Subunit VB had the deltas evolved to the extent that an associated submarine fan could reach the location of Site 603 on the basin plain. (See Sarti and von Rad, this volume, for a detailed discussion of the submarine fan facies.)

This periodic influx of terrestrially derived sediment associated with the laminated limestone at DSDP Site 603 may have initially been transported from prodelta deposits by landward-generated sediment gravity flows. Coarser clastics and the majority of the transported sediment from these currents would have been deposited on the shelf or would have aided in the seaward growth of the continental slope. Studies of modern sedimentary processes have shown that high-velocity bottom currents can stir up the seafloor periodically and are capable of transporting sands for distances before redeposition, whereas finer particles are injected into the nepheloid layer (Biscaye and Eittreim, 1977; Kennett, 1982). This suspension of lutite, if in sufficient quantity, can induce downslope flow (Ewing and Thorndike, 1965), producing a very weak current. The sediment carried in the nepheloid layer may be transported over greater distances of the basin plain area and then slowly settle out of suspension. Transport of sediment within the nepheloid layer may explain the origin of the interbedded laminated limestone with the bioturbated limestone at Site 603 .

If the laminated limestone in Subunit VB is indeed associated with the development of the Tithonian-Barremian deltas on the continental shelf, then supporting evidence should also appear in the sediments as we progress uphole. The clay mineralogy of the laminated limestone should progressively change uphole, because the site would be closer to the source as the deltas prograded seaward. As pointed out by Holmes (this volume), sorting of the clay minerals by mineral species occurs before deposition. On the basis of size and shape, kaolinite would settle out closer to the source area, whereas illite would be transported farther away, and smectite would be transported the farthest from the source area. No clay mineralogy analysis of the laminated limestone was conducted for this chapter. Selected samples of Cretaceous strata from Hole 603B were analyzed for clay mineralogy by Huff (this volume). Presented in Table 4 are data from just the laminated limestones of Unit $\mathrm{V}$ at Site 603 from Huff (this volume). These few data suggest a minor change in the clay mineral content: a decrease in smectite, with an associated increase in illite, and a gradual appearance of kaolinite as one progresses uphole. To prove that a trend of increasing kaolinite
Table 4. Clay mineralogy of laminated limestones from Hole 603B data from Huff (this volume).

\begin{tabular}{lcrcc}
\hline & & \multicolumn{3}{c}{$\begin{array}{c}\text { Percent of }<2-\mu \mathrm{m} \\
\text { clay fraction }\end{array}$} \\
\cline { 3 - 5 } $\begin{array}{c}\text { Core-Section, } \\
\text { interval or } \\
\text { level in cm }\end{array}$ & $\begin{array}{c}\text { Sub-bottom } \\
\text { depth } \\
(\mathrm{m})\end{array}$ & $\begin{array}{c}\text { Kaolinite } \\
\text { Illite }\end{array}$ & Smectite \\
\hline $52-1,123-126$ & 1292.4 & 2 & 6 & 92 \\
$52-2,21-23$ & 1292.9 & 16 & 20 & 64 \\
$54-2,96-100$ & 1312.9 & 3 & 21 & 76 \\
$66-5,70-75$ & 1430.4 & 2 & 21 & 77 \\
$76-1,77-80$ & 1512.3 & 0 & 24 & 76 \\
\hline $76-1,120$ & Base of Subunit VA & & \\
\hline $78-4,2-6$ & 1535.2 & 1 & 13 & 86 \\
$80-2,35-40$ & 1551.1 & 0 & 10 & 90 \\
\hline
\end{tabular}

content occurs from the base of Subunit VB through Subunit VA would require numerous analyses of the limestone. The bioturbated limestone, laminated limestone, and transitional limestone also display a trend of increasing organic carbon content from Subunit VB through Subunit VA. These data could also be interpreted as the result of the progradation of the delta over the continental shelf.

The periodic influxes of terrigenous sediments would have increased the contribution of nutrients and organic matter available as food for benthic organisms. Burrows that are infilled with clay-rich sediment are common in the bioturbated limestone at Site 603. The clay-rich sediment probably was obtained by infaunal organisms from the overlying surface sediment, which was enriched in terrestrially derived material or was later filled passively with this overlying sediment. The bioturbated limestone at Site 603 always has low organic carbon content because any available organic detritus was probably consumed by the infauna.

As the accumulation of the organic material increased with the terrestrially derived sediment, the dissolved oxygen content of the interstitial waters would have become depleted as the result of oxidation of organic compounds. The interstitial waters may have become anaerobic, but some burrowers could have survived if they maintained a free connection with oxygenated bottom waters (Ekdale et al., 1984). As the organic detritus continued to be deposited, the sediment/water interface may have become a dysaerobic environment with the continued depletion of available dissolved oxygen; a chemically reducing environment would then have been generated within the sediments. Laminated strata that contain no macrobenthic fauna are usually interpreted as anaerobic facies because both epibenthic organisms, and infaunal organisms that would have destroyed the laminations, require oxygenated bottom waters (Savrda and Bottjer, 1986).

Rhoads and Morse (1971) studied the distribution and diversity of benthic organisms in modern oxygen-deficient basins and compared the results with trace-fossil assemblages from pre-Cambrian and Cambrian strata. From their study, they suggested that as the dissolved oxygen content of the bottom water decreases, the size of the infaunal organisms should also decrease. This hypothesis has been tested by Savrda et al. (1984), and this 
trend of decreasing burrow size related to dissolved oxygen content has been recognized with Chondrites in the Phanerozoic rock record (Bromley and Ekdale, 1984). In addition to the decrease in burrow size with decreasing dissolved oxygen content, Savrda and Bottjer (1986) have established and modelled the tiering relationships of the infauna with variations in the paleo-oxygenation in bottom waters.

At DSDP Site 603, the ichnofabric of the bioturbated limestone does show a distinct decrease in burrow size when approaching the overlying laminated limestone, and a tiering relationship of Planolites crosscut by Chondrites. Both of these observations fit with the model of Savrda and Bottjer (1986) for decreasing oxygen content of the bottom waters. The existence of very small burrows of Chondrites within the laminated limestone at DSDP Site 603 is also evidence of very low oxygen levels in the interstitial waters. Chondrites is capable of existing in sediment characterized by an oxygen content below the levels required for other benthic organisms and usually represents the last trace fossil in a tiering relationship (Bromley and Ekdale, 1984; Savrda and Bottjer, 1986).

The decline in the dissolved oxygen content of the bottom waters associated with the onset of deposition of the laminated limestone at Site 603 is documented by the decrease in the burrow size and ichnofaunal tiering relationship in the bioturbated limestone. The dysaerobic environment of the laminated limestone generated from the continued depletion of available dissolved oxygen produced a chemically reducing environment within the sediment. The existence of this reducing environment within the laminated strata is supported by the variation in the pyrite content of the sediments. X-ray diffraction data (Mark Johns, personal communication, 1986) show an increase in the pyrite concentration in the laminated limestone by comparison to the bioturbated limestone. In addition, some specimens of Inoceramus were partially pyritized after deposition in the laminated limestone.

The association of Inoceramus with the laminated limestone also supports the interpretation that this is not an anaerobic facies. Thiede and Dinkelman's (1977) re-evaluation of the ecology of Inoceramus shows that these organisms were epibenthos that lived in a wide range of paleodepths and associated with a variety of sediments, preferring soft mud bottoms. Review of the occurrences of Inoceramus in DSDP cores reveals that the majority of the occurrences are associated with laminated, dark mudstones and chalks containing a scarcity of bioturbation (Thiede and Dinkelman, 1977) and are therefore interpreted to have been tolerant of dysaerobic environments.

The macrofossils or Inoceramus shells at Site 603 are not interpreted to have been transported downslope to the basin by the very weak bottom currents associated with nepheloid layer that deposited the laminated limestone. Thiede and Dinkelman (1977) conservatively limited the paleodepth of Inoceramus to upper bathyal and neritic environments associated with continental and island slopes and shelves. They noted that at many DSDP sites the water depth at the time of deposition of Inoce- ramus is unknown, because the subsidence profile has not been determined in many areas. Barron et al. (1984) interpret the paleodepth at DSDP Site 530 to have been between 3500 and $4500 \mathrm{~m}$ for the in situ deposition of Inoceramus. Therefore the interpretation of Inoceramus at DSDP Site 603 as being sampled in place and associated with a nearby continental setting does not disagree with what is known about the ecology of these organisms.

The oxygen isotopic composition of the Inoceramus shells yields very warm, bottom-water temperatures. There are two prevalent ideas about bottom-water circulation during the Cretaceous. One is that the water was sluggish or stagnant, having been generated in relatively warm polar regions, and reflecting warm polar surface water temperatures (Degens and Stoffers, 1976). The other is that evaporative processes in the subtropics created very warm dense saline water that dropped to the abyssal floor (Berger, 1979).

The oxygen isotopic composition of biogenic and nonbiogenic carbonate precipitated in isotopic equilibrium with seawater is interpreted to reflect changes in seawater paleotemperature with the assumption that there has been no local variations in salinity. A difference in salinity of $1 \% 0$ implies a difference of approximately $1{ }^{\circ} \mathrm{C}$ for the calculated paleotemperature (Craig, 1966). Evaporation tends to enrich residual water with the heavier oxygen isotope, ${ }^{18} \mathrm{O}$. Calculated paleotemperatures of shells precipitated in water that was more saline than thought will be less than the actual temperature (Mook, 1971; Saltzman and Barron, 1982).

The lowest oxygen isotope temperature calculated from a "reliable" Inoceramus shell is $15^{\circ} \mathrm{C}$. The temperature calculated from the belemnite, which was a nektonic organism, yielded a slightly cooler value of $11^{\circ} \mathrm{C}$. All the calculated temperatures are very warm. Either all of the samples are isotopically altered or they were not precipitated in isotopic equilibrium, or the bottom waters were indeed very warm.

Saltzman and Barron (1982) obtained temperatures from Inoceramus at Site 530 in the Angola Basin that they interpreted as evidence of saline bottom water generated by evaporation. They calculated oxygen isotope paleotemperatures on the order of 5 to $8^{\circ} \mathrm{C}$ for Pacific and Indian ocean sites with Upper Cretaceous strata containing Inoceramus and interpreted the bottom water in those areas as having been generated in the polar regions. From the temperatures calculated in this study, it appears that they fit more closely with bottom water generated in a warm equatorial region. This bottom water, although not necessarily anoxic, would contain less oxygen than polar-generated bottom water. The association of Inoceramus with only laminated sediment at Site 603 may indicate its preference to thrive in bottom waters of reduced oxygen content (Theide and Dinkelman, 1977). This preferred ecologic niche may explain the absence of these organisms in the bioturbated (well-oxygenated) nannofossil limestone.

Robertson and Bliefnick (1983) and Robertson (1984) evaluated several depositional scenarios to explain the cyclicity of the laminated limestones with the bioturbat- 
ed limestones that appeared at DSDP Site 534 in the Blake-Bahama Formation. The postulated causes ranged from diagenetic segregation, to the influence of distal turbidites, to current effects, to variations in surface productivity and influx of clay. None of these theories attempted to reconcile the paleoecology of the benthic organisms.

The association of macrofossils with laminated limestones from the Blake-Bahama Formation occurs in other locations in the North Atlantic (Fig. 14; Renz, 1972, 1978, 1979, 1983; Benson, Sheridan, et al., 1978; Hollister, Ewing, et al., 1972; Sheridan, Gradstein, et al., 1983; Tucholke, Vogt, et al., 1979). All of these sites have the sediment with the relatively largest abundance of macrofossils (that are predominantly Inoceramus) occurring before the onset of deposition of the black claystones. At DSDP Site 534, the lithology changes downhole through the most complete and thickest recovered section of the Blake-Bahama Formation, with the disappearance of the black claystones followed by the disappearance of the parallel-laminated limestones above the base of the unit (Sheridan, Gradstein, et al., 1983). All of the drill sites that recovered the Blake-Bahama Formation in the North Atlantic (Fig. 14) have laminated limestones appearing before the deposition of the claystone turbidites. Perhaps all of the laminated limestones of the Blake-Bahama Formation were deposited by very weak bottom currents associated with the nepheloid layer and may have been distantly related to the development of the Tithonian-Barremian deltas on the inner and middle continental shelf.

\section{CONCLUSIONS}

The periodic influx of clay, very fine grained sand, and terrigenous organic matter is interpreted to have resulted in the interbedded nature of the laminated limestone with the bioturbated limestone at Site 603. The deposition of intervals of laminated limestone associated with bioturbated limestone anteceded the deposition of claystone turbidites and perhaps indicates the progradation of the Tithonian-Barremian deltas that developed on the inner and middle continental shelf. Not until the deposition of Subunit VB had the deltas sufficiently developed to have an associated submarine fan reach the location of Site 603 on the basin plain. The periodic influx of terrestrially derived sediment associated with the laminated limestone at DSDP Site 603 may have initially been transported from prodelta deposits and subsequently been transported within the nepheloid layer. Deposition of these influxes of terrigenous detritus from the nepheloid layer may explain the origin of the interbedded laminated limestone and bioturbated limestone at Site 603. The Inoceramus shells at Site 603 are interpreted to be in situ; these have not been transported downslope to the basin by the very weak bottom currents associated with the nepheloid layer that deposited the laminated limestone.

The decline in the dissolved oxygen content of the bottom waters associated with the onset of deposition of the laminated limestone at Site 603 is documented by the decrease in the burrow size and ichnofaunal tiering relationship in the bioturbated limestone. The associa- tion of Inoceramus with the laminated limestone also supports the interpretation that this is a dysaerobic facies.

The lowest oxygen isotope temperature calculated from a "reliable" Inoceramus shell is $15^{\circ} \mathrm{C}$. The temperature calculated from the belemnite, which was a nektonic organism, yielded a slightly cooler value of $11^{\circ} \mathrm{C}$. All the calculated oxygen isotope paleotemperatures are very warm. Either all of the samples are isotopically altered, or they were not precipitated in isotopic equilibrium, or the bottom waters were indeed very warm. If these paleotemperatures calculated from the Inoceramus are reliable, then the bottom waters were very warm and may have been generated in the equatorial region.

\section{ACKNOWLEDGMENTS}

The author thanks her shipboard colleagues for stimulating and interesting discussions about the Blake-Bahama Formation. Stable isotope compositions were determined at the Stable Isotope Laboratory at the AMOCO Production Company, Research Center. Organic geochemistry data were provided by Phil Meyers, and X-ray diffraction data were provided by Mark Johns. This paper benefited from the reviews by Dennis Prezbindowski, Paul Aharon, and an anonymous reviewer. The author also acknowledges the University of Tulsa for receipt of a grant from the Faculty Reseach Program to support this study.

\section{REFERENCES}

Barron, E. H., Saltzman, E. S., and Price, D. A., 1984. Occurrence of Inoceramus in the South Atlantic and oxygen isotopic paleotemperatures in Hole 530A. In Hay, W. W., Sibuet, J.-C., et al., Hole 530A. Init. Repts DSDP, 75, Pt. 2: Washington (U.S. Govt. Printing Office), 893-904.

Benson, W. E., Sheridan, R. E., et al., 1978. Init. Repts. DSDP, 44: Washington (U.S. Govt. Printing Office).

Berger, W. H., 1979. Impact of deep sea drilling on paleoceanography. In Talwani, M., Hay, W., and Ryan, W. B. F. (Eds.), Deep Drilling Results in the Atlantic Ocean: Continental Margins and Paleoenvironment: Washington, D.C. (Am. Geophys. Union), Maurice Ewing Series, 3:297-314.

Biscaye, P. E., and Eittreim, S. L., 1977. Suspended particulate loads and transports in the nepheloid layer of the abyssal Atlantic Ocean. Mar. Geol., 23:155-172.

Bromley, R. G., and Ekdale, A. A., 1984. Chondrites: a trace fossil indicator of anoxia in sediments. Science, 224:872-874.

Craig, H., 1966. Isotopic composition and origin of the Red Sea and Salton Sea geothermal brines. Science, 154:1544-1548.

Degens, E. T., and Stoffers, P., 1976. Stratified waters as a key to the past. Nature, 263:22-27.

Eckdale, A. A., Bromley, R. G., and Pemberton, S. G., 1984. Ichnology: The Use of Trace Fossils in Sedimentology and Stratigraphy: Tulsa (Soc. Econ. Paleontol. Mineral.), SEPM Short Course No. 15.

Ewing, M., and Thorndike, E. M., 1965. Suspended matter in deep ocean water. Science, 147:1291-1294.

Gieskes, J.M., 1981. Deep-sea drilling interstitial water studies: implications for chemical alteration of the oceanic crust, Layers I and II. In Warmes, J. E., Douglas, R. G., and Winterer, E. L. (Eds.), The Deep-Sea Drilling Project: A Decade of Progress. Soc. Econ. Paleontol. Mineral. Spec. Publ., 32:149-167.

Hollister, C. D., Ewing, J. I., et al., 1972. Init. Repts. DSDP, 11: Washington (U.S. Govt. Printing Office).

Jansa, L. F., Enos, P., Tucholke, B. E., Gradstein, F. M., and Sheridan, R. E., 1979. Mesozoic-Cenozoic sedimentary formations of the North American Basin; western North Atlantic. In Talwani, M., Hay, W., and Ryan, W. B. F. (Eds.), Deep Drilling Results in the Atlantic Ocean: Continental Margins and Paleoenvironment: Washington, D.C. (Am. Geophys. Union), Maurice Ewing Series, $3: 1-57$.

Kennett, J. P., 1982. Marine Geology: Englewood Cliffs (Prentice-Hall). 
Lehmann, U., 1979. Aptychus, Anaptychus. In Fairbridge, R. W., and Jablonski, D. (Eds.), Encyclopedia of Paleontology: Stroudsburg, PA (Dowden, Hutchinson, and Ross, Inc.), Encyclopedia of Earth Sciences, 7:45-46.

Lowenstam, H., and Epstein, S., 1954. Paleotemperatures of the postAptian Cretaceous as determined by oxygen isotope method. $J$. Geol., 62:207-248.

McCrea, J. M., 1950. On the isotopic chemistry of carbonates and a paleotemperature scale. J. Chem. Physics, 18:849-857.

Majewske, O., 1974. Recognition of Invertebrate Fossil Fragments in Rocks and Thin Sections: Netherlands (E. J. Brill), International Sedimentary Petrographical Series, 8.

Mook, W. G., 1971. Paleotemperatures and chlorinities from stable carbon and oxygen isotopes in shell carbonate. Palaeogeogr. Palaeoclimatol., Palaeoecol., 9:245-263.

Mutti, E., and Ricci Lucchi, F., 1972. Le torbiditi dell'Appennino settentrionale: introduzione all'analisi di facies. Mem. Soc. Geol. Ital., pp. 161-199. (Translated into English: 1978. Turbidites of the Northern Apennines: introduction to facies analysis. Int. Geol. Rev., 20: 125-166.)

Renz, O., 1972. Aptychi (Ammonoidea) from the Upper Jurassic and Lower Cretaceous of the western North Atlantic (Site 105, Leg 11, DSDP). In Hollister, C. D., Ewing, J. I., et al., Init. Repts. DSDP, 11: Washington (U.S. Govt. Printing Office), 607-630.

1978. Aptychi (Ammononoidea) from the Early Cretaceous of the Blake-Bahama Basin, Leg 44, Hole 391C, DSDP. In Benson, W. E., Sheridan, R. E., et al., Init. Repts. DSDP, 44: Washington (U.S. Govt. Printing Office), 899-909. 1979. Aptychi (Ammonoidea) and ammonites from the Lower Cretaceous of the Western Bermuda Rise, Leg 43, Site 387 , DSDP. In Tucholke, B. E., Vogt, P. R., et al., Init. Repts. DSDP, 43: Washington (U.S. Govt. Printing Office), 591-597.

, 1983. Early Cretaceous Cephalopoda from the Blake-Bahama Basin (Deep Sea Drilling Project Leg 76, Hole 534A) and their correlation in the Atlantic and southwestern Tethys. In Sheridan, R. E., Gradstein, F. M., et al., Init. Repts. DSDP, 76: Washington (U.S. Govt. Printing Office), 639-644.

Rhoads, D.C., and Morse, J. W., 1971. Evolutionary and ecologic significance of oxygen-deficient marine basins. Lethaia, 4:413-428.

Robertson, A. H. F., 1984. Origin of varve-type lamination, graded claystones and limestone-shale "couplets" in the Lower Cretaceous of the western North Atlantic. In Stow, D. A. V., and Piper, D. J. W. (Eds.), Fine-Grained Sediments: Deep-Water Processes and Facies: Boston (Blackwell Scientific), pp. 437-452.
Robertson, A. H. F., and Bliefnick, D. M., 1983. Sedimentology and origin of Lower Cretaceous pelagic carbonates and redeposited clastics, Blake-Bahama Formation, Deep Sea Drilling Project Site 534, Western Equatorial Atlantic. In Sheridan, R. E., Gradstein, F. M., et al., Init. Repts. DSDP, 76: Washington (U.S. Govt. Printing Office), 795-827.

Saltzman, E. S., and Barron, E. J., 1982. Deep circulation in the Late Cretaceous: oxygen isotope paleotemperatures from Inoceramus remains in DSDP cores. Palaeogeogr., Palaeoclimatol., Palaeoecol., 40:167-181.

Savrda, C. E., and Bottjer, D. J., 1986. Trace-fossil model for reconstruction of paleo-oxygenation in bottom waters. Geology, 14:3-6.

Savrda, C. E., Bottjer, D. J., and Gorsline, D. S., 1984. Development of a comprehensive oxygen deficient marine biofacies model: evidence from Santa Monica, San Pedro, and Santa Barbara basins, California continental borderland. Am. Assoc. Pet. Geol. Bull., 68:1179-1192.

Shackleton, N. J., and Kennett, J. P., 1975. Paleotemperature history of the Cenozoic and the initiation of Antarctic glaciation: oxygen and carbon isotope analyses in DSDP Sites 277, 279, and 281. In Kennett, J. P., Houtz, R. E., et al., Init. Repts. DSDP, 29: Washington (U.S. Govt. Printing Office), 743-755.,

Sheridan, R. E., Gradstein, F. M., et al., 1983. Init. Repts. DSDP, 76: Washington (U.S. Govt. Printing Office).

Stevens, G. R., and Clayton, R. N., 1971. Oxygen isotope studies on Jurassic and Cretaceous belemnites from New Zealand and their biogeographic significance. N.Z. J. Geol. Geophys., 14:829-897.

Thiede, J., and Dinkelman, M. G., 1977. Occurrence of Inoceramus remains in late Mesozoic pelagic and hemipelagic sediments. In Supko, P. R., Perch-Nielsen, K., et al., Init. Repts. DSDP, 39: Washington, D.C. (U.S. Govt. Printing Office), 899-910.

Tucholke, B.E., Vogt, P.R., et al., 1979. Init. Repts. DSDP, 43: Washington (U.S. Govt. Printing Office).

Uchupi, E., 1971. Bathymetric atlas of the Atlantic, Caribbean and Gulf of Mexico. Woods Hole Oceanographic Institution Ref. No. 71-72.

Weber, J. N., and Woodhead, P. M. J., 1972. Temperature dependence of oxygen-18 concentration in reef coral carbonates. J. Geophys. Res., 77:463-473.

Yapp, C. J., 1979. Oxygen and carbon isotopic measurements of land snail shell carbonate. Geochim. Cosmochim. Acta, 43:629-635.

Date of Initial Receipt: 6 August 1985

Date of Acceptance: 4 June 1986 


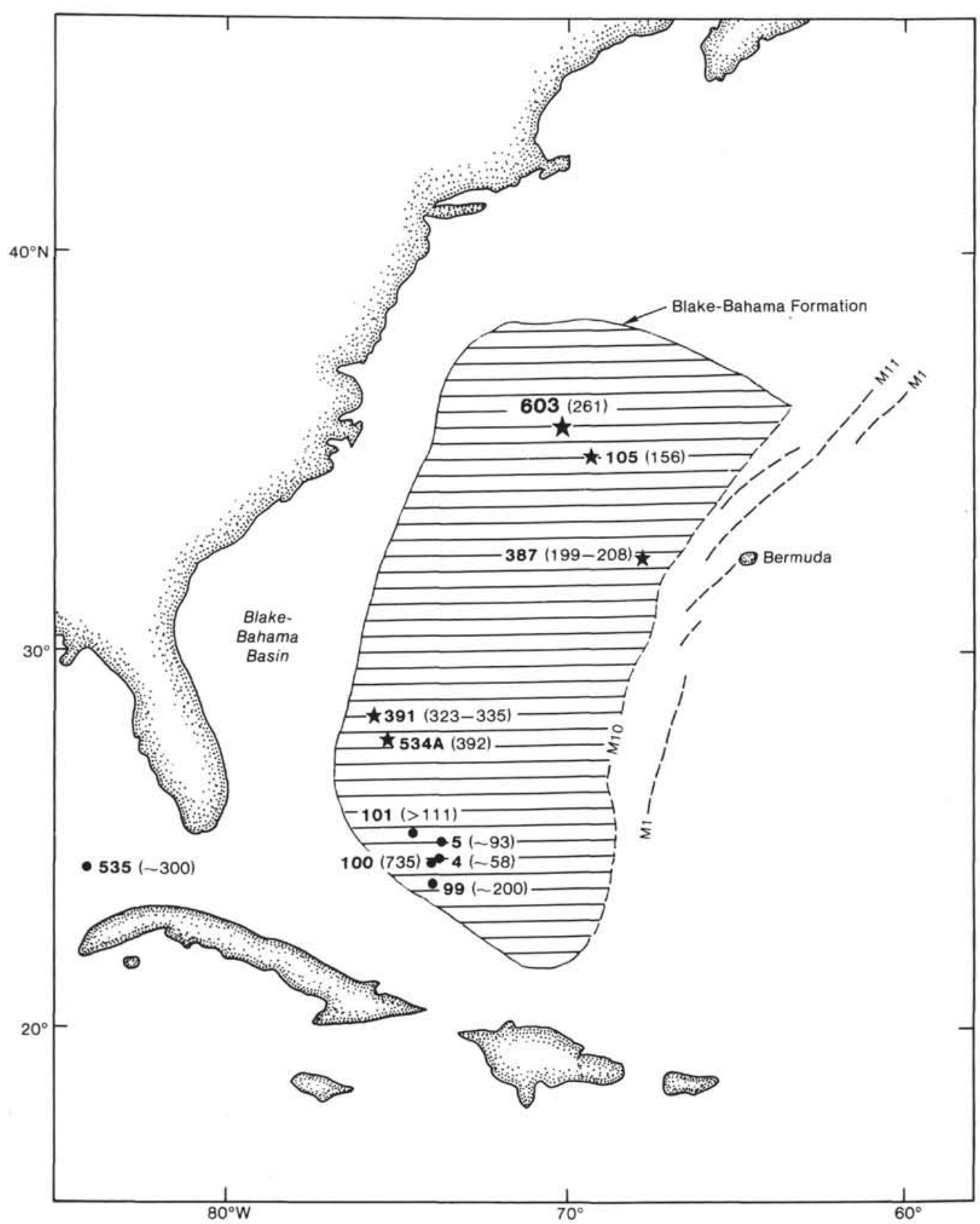

Figure 14. Map showing the geographic extent of the deposition of Early Cretaceous pelagic limestones with the location of DSDP sites drilled in the western Central Atlantic. The DSDP sites located with a star are sites reported to have macrofossils contained in Cretaceous limestone. Thickness in meters of the Blake-Bahama Formation is shown in parentheses. Horizon $\beta$ correlates approximately with the top of the Blake-Bahama Formation, and the eastern boundary indicates pinch-out against basement near Magnetic Anomaly M-11 that has been interpreted as Valanginian in age. This figure is a modification of figure 1 in Robertson and Bliefnick (1983), which is also modified after Jansa et al., 1979. 